\title{
Streambed Scour of Salmon (Oncorhynchus spp.) Redds in the Sauk River, Northwestern Washington
}

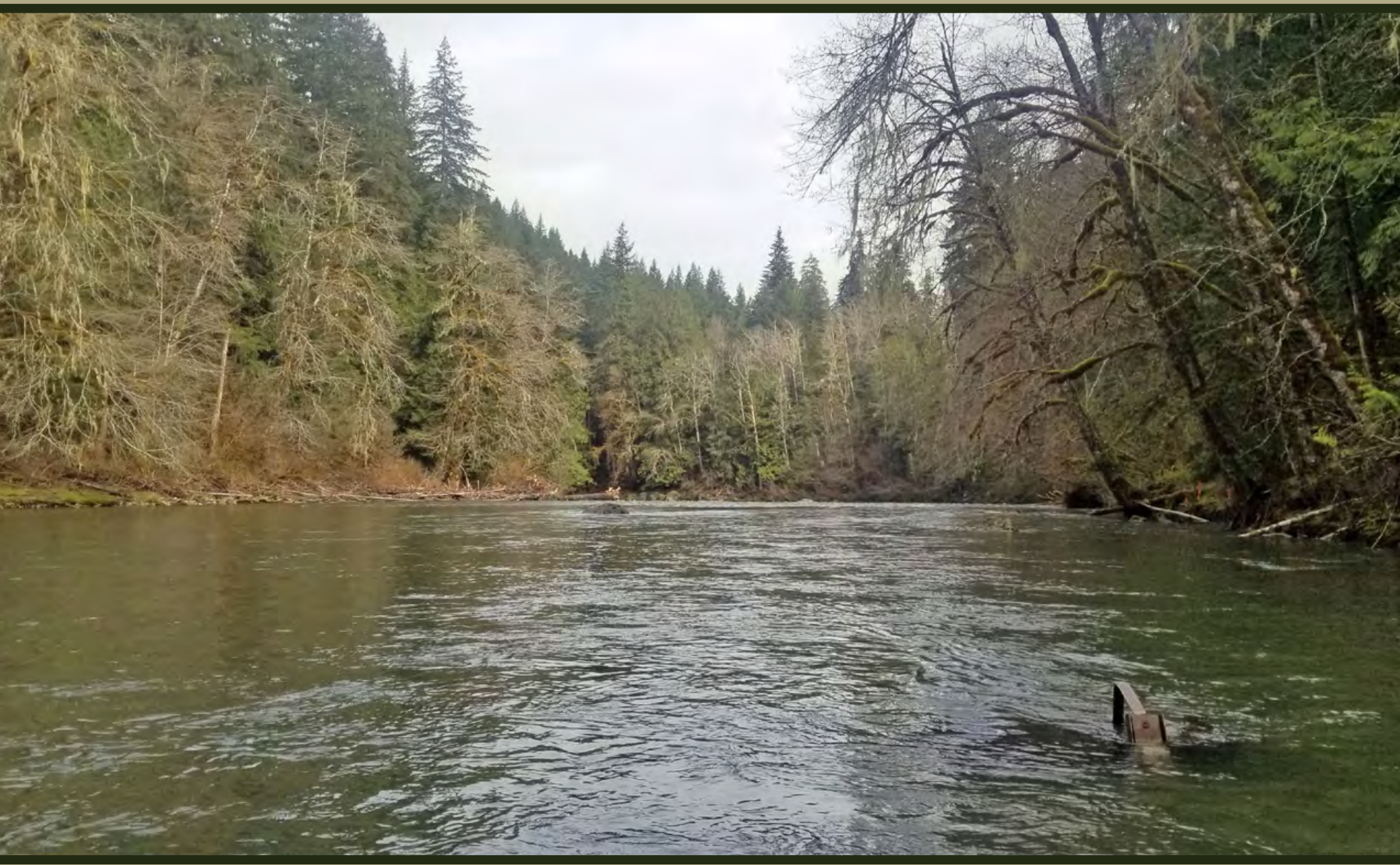

Scientific Investigations Report 2021-5133

U.S. Department of the Interior U.S. Geological Survey 
Cover. View of Sauk River looking downstream from U.S. Geological Survey (USGS) streamgage Sauk River above White Chuck River, near Darrington, Washington (12186000). Photograph by Will Wright, U.S. Geological Survey, April 12, 2019. 


\section{Streambed Scour of Salmon (Oncorhynchus spp.) Redds in the Sauk River, Northwestern Washington}

By Andrew S. Gendaszek

Prepared in cooperation with the Sauk-Suiattle Indian Tribe

Scientific Investigations Report 2021-5133 


\section{U.S. Geological Survey, Reston, Virginia: 2021}

For more information on the USGS - the Federal source for science about the Earth, its natural and living resources, natural hazards, and the environment—visit https://www.usgs.gov or call 1-888-ASK-USGS.

For an overview of USGS information products, including maps, imagery, and publications, visit https://store.usgs.gov/.

Any use of trade, firm, or product names is for descriptive purposes only and does not imply endorsement by the U.S. Government.

Although this information product, for the most part, is in the public domain, it also may contain copyrighted materials as noted in the text. Permission to reproduce copyrighted items must be secured from the copyright owner.

Suggested citation:

Gendaszek, A.S., 2021, Streambed scour of salmon (Oncorhynchus spp.) redds in the Sauk River, Northwestern Washington: U.S. Geological Survey Scientific Investigations Report 2021-5133, 19 p., https://doi.org/10.3133/ sir20215133.

Data release:

Gendaszek, A.S, 2021, Accelerometer scour monitor data on the Sauk River, Washington, Water Year 2018: U.S. Geological Survey data release, https://doi.org/10.5066/P95KOMTC.

ISSN 2328-0328 (online) 


\section{Contents}

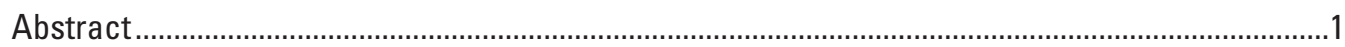

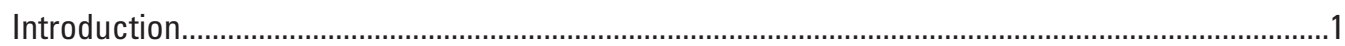

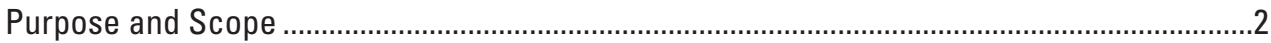

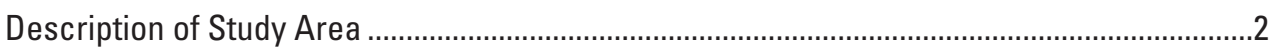

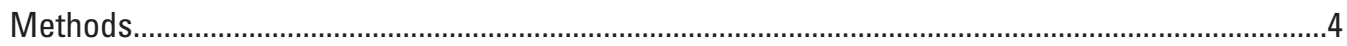

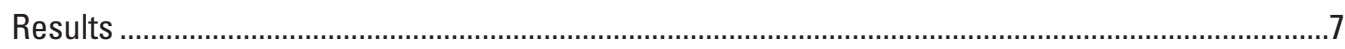

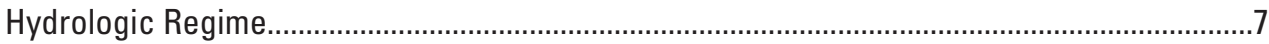

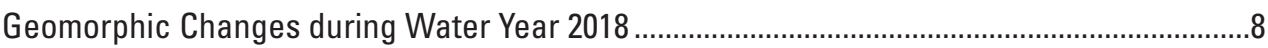

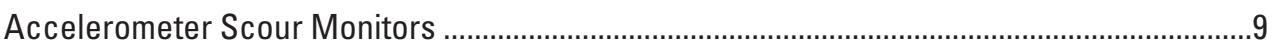

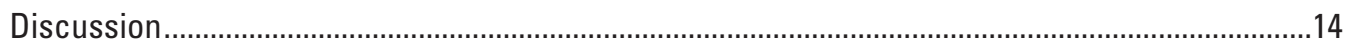

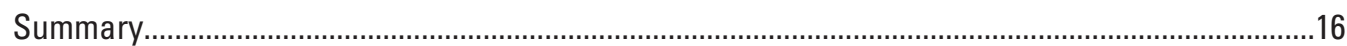

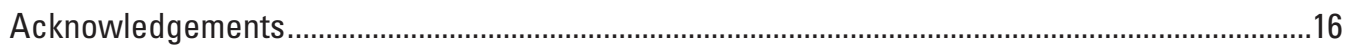

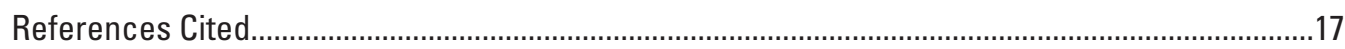

\section{Figures}

1. Map showing locations of study reaches in Sauk River basin, Snohomish and Skagit Counties, northwestern Washington ..

2. Aerial orthoimagery showing locations of accelerometer scour monitor deployments and transects at the upstream reach of the Sauk River near river mile 32.2, northwestern Washington

3. Aerial orthoimagery showing locations of accelerometer scour monitor deployments and transects at the downstream reach of the Sauk River near river mile 17.8, northwestern Washington.

4. Schematic of accelerometer scour monitor deployment.................................................7

5. Discharge measured at U.S. Geological Survey streamgage 12186000, northwestern Washington, water year 2018.

6. Transects F-I surveyed before and after water year 2018 flood season and locations of accelerometer scour monitors at the downstream reach of the Sauk River near river mile 17.8, northwestern Washington..

7. Transects A-E surveyed before and after water year 2018 flood season and locations of accelerometer scour monitors at the upstream reach of the Sauk River near river mile 32.2, northwestern Washington

8. Graphs showing discharge and duration of initial scour and final fill during October 2017 peak-flow event, northwestern Washington..

9. Graphs showing discharge and duration of initial scour and final fill during November 2017 peak-flow event, northwestern Washington

10. Graphs showing tilt recorded by upper and lower accelerometers of ASM-9 during the October peak-flow event, northwestern Washington.

11. Graphs showing tilt recorded by upper and lower accelerometers of ASM-9 during the November peak-flow event, northwestern Washington .. 


\section{Tables}

1. Annual exceedance probabilities estimated for U.S. Geological Survey streamgage at Sauk River above White Chuck River, near Darrington, Washington (12186000)

2. Accelerometer scour monitor site characteristics, northwestern Washington, water year 2018.

3. Temporal record of scour recorded and geomorphic data for accelerometer scour monitors deployed, northwestern Washington, water year 2018

\section{Conversion Factors}

U.S. Customary Units to International System of Units

\begin{tabular}{|c|c|c|}
\hline Multiply & By & To obtain \\
\hline \multicolumn{3}{|c|}{ Length } \\
\hline foot $(\mathrm{ft})$ & 0.3048 & meter $(\mathrm{m})$ \\
\hline mile (mi) & 0.393701 & kilometer (km) \\
\hline \multicolumn{3}{|c|}{ Area } \\
\hline acre & 0.4047 & hectare (ha) \\
\hline square mile $\left(\mathrm{mi}^{2}\right)$ & 2.590 & square kilometer $\left(\mathrm{km}^{2}\right)$ \\
\hline \multicolumn{3}{|c|}{ Flow rate } \\
\hline cubic foot per second $\left(\mathrm{ft}^{3} / \mathrm{s}\right)$ & 0.02832 & cubic meter per second $\left(\mathrm{m}^{3} / \mathrm{s}\right)$ \\
\hline \multicolumn{3}{|c|}{ International System of Units to U.S. Customary Units } \\
\hline Multiply & By & To obtain \\
\hline \multicolumn{3}{|c|}{ Length } \\
\hline $\mathrm{cm}$ (centimeter) & 1.609 & inch \\
\hline meter $(\mathrm{m})$ & 3.28084 & foot $(\mathrm{ft})$ \\
\hline millimeter $(\mathrm{mm})$ & 0.03937008 & inch (in.) \\
\hline \multicolumn{3}{|c|}{ Pressure } \\
\hline millimeter $(\mathrm{mm})$ & 0.014223343911903 & pound per square inch $\left(\mathrm{lb} / \mathrm{in}^{2}\right)$ \\
\hline
\end{tabular}

Temperature in degrees Celsius $\left({ }^{\circ} \mathrm{C}\right)$ may be converted to degrees Fahrenheit $\left({ }^{\circ} \mathrm{F}\right)$ as follows:

$$
{ }^{\circ} \mathrm{F}=\left(1.8 x^{\circ} \mathrm{C}\right)+32
$$

Temperature in degrees Fahrenheit $\left({ }^{\circ} \mathrm{F}\right)$ may be converted to degrees Celsius $\left({ }^{\circ} \mathrm{C}\right)$ as follows:

$$
{ }^{\circ} \mathrm{C}=\left({ }^{\circ} \mathrm{F}-32\right) / 1.8
$$

Vertical coordinate information is referenced to North American Vertical Datum of 1988 (NAVD 88).

Horizontal coordinate information is referenced to North American Datum of 1983 (NAD 83).

Elevation, as used in this report, refers to distance above the vertical datum. 


\title{
Streambed Scour of Salmon (Oncorhynchus spp.) Redds in the Sauk River, Northwestern Washington
}

\author{
By Andrew S. Gendaszek
}

\section{Abstract}

The autumn and winter flood season of western Washington coincides with the incubation period of many Pacific salmon (Onchorhynchus spp.) populations. During this period, salmon embryos incubating within gravel nests called "redds" are vulnerable to mobilization of surrounding sediment during floods. As overlying sediment is transported downstream, the vertical position of the streambed can be lowered, a process termed streambed scour; thus developing salmon embryos may be destroyed resulting in decreasing egg-to-fry survival rates. The Sauk River, which drains a $1,900 \mathrm{~km}^{2}\left(733.5 \mathrm{mi}^{2}\right)$ area of the central Cascade Range of Washington State, provides spawning and rearing habitat for several species of Pacific salmon including Chinook salmon (O. tshawytscha), which were listed as threatened under the Endangered Species Act (ESA) in 1999. In order to assess the hydrologic conditions when streambed scour and concomitant geomorphic changes occur, accelerometer scour monitors (ASMs), which record the time when streambed scour lowers the streambed to the level of salmon egg pockets, were deployed in two geomorphically different reaches of the Sauk River to monitor scour during water year 2018. Nineteen ASMs were deployed in an upstream reach, which was largely confined by valley walls with vegetated, stable banks and low channel-migration rates near the confluence of the Sauk and White Chuck Rivers. Twelve additional ASMs were deployed in a downstream reach within an unconfined valley with unvegetated, unstable banks and high channel-migration rates between the town of Darrington and the confluence of the Sauk and Suiattle Rivers. During the ASM deployment, discharge measured at the U.S. Geological Survey (USGS) streamgage Sauk River above White Chuck River, near Darrington, Washington (12186000), peaked at $479 \mathrm{~m}^{3} / \mathrm{s}$ $\left(16,900 \mathrm{ft}^{3} / \mathrm{s}\right)$ with an estimated 0.18 probability of annual exceedance (5.7-year recurrence interval). During the flood season, large-scale geomorphic changes, including channel migration and bar deposition, were measured at the downstream reach, but only minimal geomorphic changes were measured at the upstream reach. ASMs deployed at the downstream reach were not recovered after the flood season and total scour depth was presumed to have exceeded ASM anchor depth. At the upstream reach, 7 of the 19 deployed ASMs were recovered after the flood season and all recovered ASMs recorded scour at discharges that equaled or exceeded 204 $\mathrm{m}^{3} / \mathrm{s}\left(7,210 \mathrm{ft}^{3} / \mathrm{s}\right)$. The remaining 12 ASMs deployed at the upstream reach were not recovered and total scour depth was presumed to have exceeded ASM anchor depth. Collectively, this analysis enhances the ability of fisheries managers to forecast egg-to-fry survival rates of salmonids by determining the hydrologic conditions at which scour at the level of salmon redds initiates.

\section{Introduction}

The viability of Pacific salmon (Oncorhynchus spp.) populations depends on freshwater and marine environmental conditions during several distinct life-history stages. Among the most vulnerable periods for salmon in freshwater is the incubation period between spawning and emergence as fry from gravel nests called redds, which are constructed by female salmon to protect incubating embryos from predation and disturbance (Smirnova, 1955). During incubation, developing salmon embryos are immobile within the streambed and subject to the infiltration of fine-grained sediment that may reduce permeability of redds and limit the supply of oxygenated water (Lisle, 1989) as well as the scour of redds from sediment mobilization and net lowering of the streambed during floods (Montgomery and others, 1996). Negative correlations between egg-to-fry survival rates and peak discharge during the incubation period have been measured in several salmon-bearing streams in the Pacific Northwest (Holtby and Healey, 1986; Thorne and Ames, 1987; Greene and others, 2005; Gibbins and others, 2008), but few studies have isolated the effect of streambed scour on egg mortality during incubation (for example, Cunjak and others, 1998).

Salmon have adapted to the flood regimes and associated risk of streambed scour of their natal streams by evolving life-history strategies that determine the timing of migration, spawning, and incubation of their eggs (Waples and others, 2008). In addition, salmon mitigate the risk of redd scour during floods by preferentially spawning in areas of the channel where shear stress on the streambed is lower during floods and redds are less susceptible to scour (LaPointe and others, 2000; May and others, 2009; Moir and others, 2009; Shellberg and 
others, 2010; McKean and Tonina, 2013). Hydraulic conditions and the size of spawning gravels also may play a role in the selection of adults because larger females are able to dig deeper redds that protect incubating salmon eggs from deeper scour (Steen and Quinn, 1999). Montgomery and others (1999) hypothesized that the depth of streambed scour constrains salmon populations because they could not persist in rivers where floods consistently induce scour that exceeds the depth of incubating egg pockets. This hypothesis is supported by Montgomery and others (1996) who documented egg-pocket depths below maximum scour depths during bank-full floods in Pacific Northwest streams, which suggests that increases in the frequency of scour below this depth could deleteriously impact salmon populations by reducing egg-tofry survival.

Like other aquatic species, native salmon have evolved and adapted to episodic disturbances such as floods and droughts, but it is unknown if they can adapt to projected changes in the magnitude and frequency of such disturbances (Waples and others, 2008). In a salmon-bearing, snowmeltdominated stream in the northern Rocky Mountains, Goode and others (2013) concluded that projected increases in the frequency and magnitude of floods during the incubation period may be mitigated, in part, by refugia in parts of the stream network where the channel is unconfined. At these locations within low-flow channels where spawning occurs, shear stress reaches its peak at bankfull discharge; because at higher discharges, floodwater is conveyed across the floodplain. In western Washington, the autumn and winter flood season coincides with the incubation period of many salmon populations making them vulnerable to streambed scour during floods. During the 21st century, the magnitude and frequency of flooding in western Washington is projected to increase from historical norms due to increased magnitude and frequency of atmospheric rivers that convey subtropical moisture to the Pacific Northwest in a narrow, focused band termed an atmospheric river resulting in high-intensity rainfall (Warner and others, 2015; Gershunov and others, 2019). In addition, the ability of salmon to respond to potential increases in the magnitude and frequency of scour events through increased egg burial depth, for example, may be constrained by external factors like selective-size fisheries, breeding with hatchery fish, and changes in ocean productivity, which favor the selection of smaller adults that bury eggs at shallow depths (Waples and others, 2008). Information about the hydrologic conditions when streambed scour occurs at the depth of salmon redd pockets in different geomorphic settings is needed to inform management of salmon fisheries and assess how projected changes in flood hydrology may impact restoration efforts.
The timing of streambed scour in Chinook salmon $(O$. tshawytscha) spawning habitat was measured using accelerometer scour monitors (ASMs; Gendaszek and others, 2013) and analyzed in the context of hydrologic conditions within two geomorphically distinct reaches of the Sauk River, a tributary of the Skagit River that drains part of the Cascade Range of northwestern Washington (fig. 1). The Sauk River supports several species of salmon, which like other stocks in Puget Sound, have declined during the 20th century (Nehlsen and others, 1991), resulting in the listing of several salmon species, including Chinook salmon, under the Endangered Species Act (ESA) within Puget Sound (National Marine Fisheries Service, 2005). In order to assess the vulnerability of salmon redds to streambed scour under different geomorphic conditions of the Sauk River, the discharge when scour initiated at the depth of incubating salmon redds was determined.

\section{Purpose and Scope}

The purpose of this report is to assess the hydrologic conditions when streambed scour occurs at the depth of egg pockets in salmon redds in two geomorphically distinct reaches of the Sauk River during water year 2018 when two peak-flow events with annual exceedance probabilities of 0.18 and 0.49 occurred. The timing of streambed scour was assessed using ASMs within two reaches of the Sauk River(1) a single-threaded reach just upstream from the confluence of the Sauk and White Chuck Rivers within a narrow, confined valley and (2) a multi-threaded reach downstream within the broad, unconfined valley of the Sauk River between the city of Darrington and the confluence of the Sauk and Suiattle Rivers.

\section{Description of Study Area}

The Sauk River and its primary tributary, the Suiattle River, drain a $1,900 \mathrm{~km}^{2}\left(733.5-\mathrm{mi}^{2}\right)$ area of the Cascade Range upstream of its confluence with the Skagit River (fig. 1). Elevation of the Sauk River basin ranges from 3,213 $\mathrm{m}(10,541 \mathrm{ft})$ at the summit of Glacier Peak to $65.5 \mathrm{~m}(215 \mathrm{ft})$ at its confluence with the Skagit River. The Sauk River basin is bisected by the Straight Creek Fault, a north-south trending strike-slip fault, which separates medium to high-grade metamorphic bedrock to the east from low-grade metamorphic bedrock to the west (Tabor and others, 2002). During the Quaternary, alpine glaciers and the Puget Lobe of the Cordilleran ice sheet eroded valleys of the Sauk River and its tributaries and deposited thick sequences of unconsolidated sediments that have subsequently been reworked by rivers during the Holocene. 


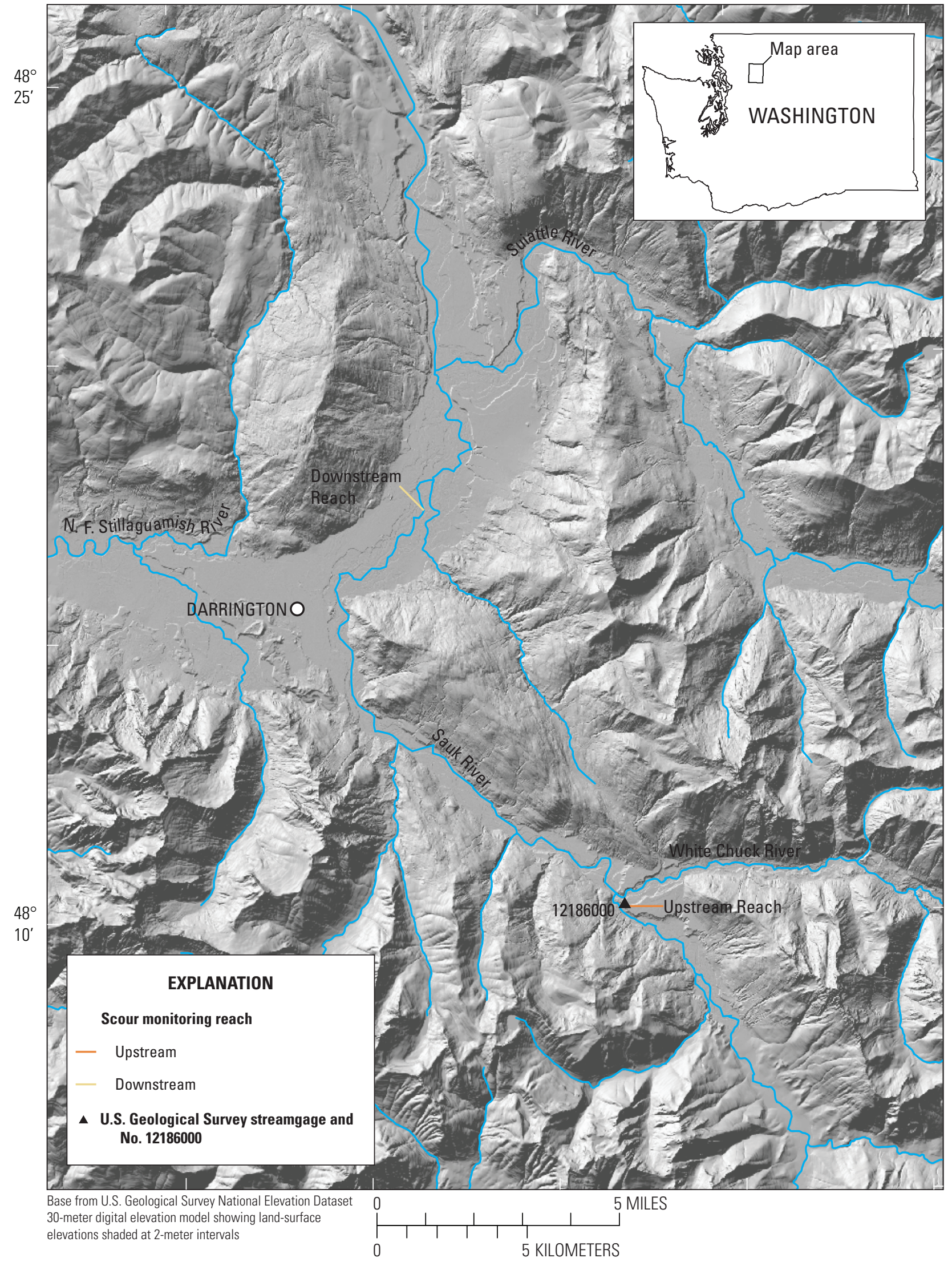

Figure 1. Locations of study reaches in Sauk River basin, Snohomish and Skagit Counties, northwestern Washington. 
The present course of the Sauk River into the Skagit River was established after a complex series of events following the most recent retreat of the Puget Lobe at the end of the Vashon stade of the Fraser glaciation (Tabor and others, 2002). As the Puget Lobe retreated northward, glacial sediments blocked the Skagit River drainage forcing the Sauk River to drain westward through the modern valley of the North Fork Stillaguamish River. This blockage was eventually breached, but the Sauk River was not diverted into its modern drainage path until deposition of a lahar in the Sauk River and North Fork Stillaguamish River valleys following a Holocene eruption of Glacier Peak 12,500 years ago (Dragovich and McKay, 2000). Deposition of this lahar where the Sauk River valley widens near the town of Darrington altered topography of the low divide and thus diverted the Sauk River to the north and leaving the North Fork Stillaguamish River as an underfit stream in the former course of the Sauk River.

Upstream of Darrington, the Sauk River forms a largely single-threaded channel within a narrow, confined valley. The Sauk River valley widens at Darrington and the Sauk River changes to a braided, multi-threaded channel within a wide, unconfined valley downstream of Darrington. Channel migration rates are considerably higher downstream of Darrington, and large, unvegetated bars are reworked by successive floods. Conversely, channel migration rates are lower upstream of Darrington, and banks are largely vegetated by mature trees. The Sauk River conveys high sediment loads from tributaries that drain active glaciers of Glacier Peak, as well as reworked unconsolidated glacial and volcanic sediments (Jaeger and others, 2017).

The discharge regime of the Sauk River is driven by cool, wet winters and warm, dry summers. During the autumn and winter, precipitation falls as rain at low to middle elevations with snow falling and accumulating at high elevations. Melting of the mountain snowpack results in a prolonged period of elevated discharge between April and June during the spring freshet. Most floods, however, in this mixed rainsnow drainage basin occur as short-lived, discrete events during the autumn from high-intensity rainfall resulting from the conveyance of subtropical moisture to the Pacific Northwest in a narrow, focused band termed an atmospheric river (Neiman and others, 2011). Streamflow typically reaches its annual minimum base flow during August and September after the spring freshet and before the onset of autumn precipitation.

\section{Methods}

Accelerometer scour monitors (ASMs; Gendaszek and others, 2013) were deployed in two reaches of the Sauk River at river miles (RM) 32.2 and 17.8 in August 2017 before the water year 2018 flood season to determine when streambed scour mobilized sediment at the depth of incubating salmonid redds. Nineteen ASMs were deployed at RM 32.2 within five transects (A-E) of the main channel of the Sauk River upstream of its confluence with the White Chuck River near
USGS streamgage 12186000 (fig. 2). An additional 12 ASMs were deployed within four transects (F-I) of a secondary channel of the Sauk River at RM 17.8 (fig. 3). The reaches at RMs 32.2 and 17.8 are referred to as the "upstream reach" and "downstream reach," respectively, in this report.

Each ASM was comprised of two accelerometers, which were deployed in series to two depths of the streambed using a hand-driven pounding device like that described by Klassen and Northcote (1986). The streambed at each ASM location was minimally disturbed by the pounding device, which compacted the surrounding gravel matrix to create the $6-\mathrm{cm}$ diameter hole into which each ASM was inserted. Passive integrated transponders (PIT) tags were attached to the upper accelerometer of each ASM to facilitate their post-flood season recovery. The upper and lower accelerometers of each ASM were deployed to targeted depths of 15 and $30 \mathrm{~cm}$ below the streambed, respectively, with the anchor of each accelerometer deployed to a depth of approximately $50 \mathrm{~cm}$ below the streambed (fig. 4). Actual installation depths varied from these target depths because of variation in site conditions and at three ASM locations (ASM-20, ASM-21, and ASM-30); site conditions precluded installation of a lower accelerometer. The median installation depth of upper accelerometers was $12 \mathrm{~cm}$ (range: 4-17 cm) and the median installation depth of lower accelerometers was $28 \mathrm{~cm}$ (range: 19-32 cm). The depth of the upper accelerometer was targeted to $15 \mathrm{~cm}$ based on DeVries' (1997) review of published egg-pocket depths within Chinook redds and represented the maximum allowable depth before initial scour of the top of the egg pocket. The lower accelerometer was placed at an intermediate depth $(30 \mathrm{~cm})$, and the ASM anchor depth $(50 \mathrm{~cm})$ represented the maximum allowable depth of scour before the bottom of the egg pocket was scoured. The location of each ASM and the pre-flood season elevation of the adjacent streambed was measured in the downstream reach using a real-time kinematic global positioning system (RTK-GPS) and in the upstream reach relative to a local network of benchmarks using a Total Station due to poor GPS coverage. The horizontal distance of each ASM relative to three benchmarks also was measured using a measuring tape after ASM deployment to facilitate post-flood season retrieval of ASMs in the upstream reach.

The accelerometers of each ASM were programmed to record their three-dimensional orientation every 15 minutes beginning October 1, 2017, through May of the following year. Accelerometers remained at a constant orientation until streambed scour reached the depth of the accelerometer and the surrounding gravel matrix moved as overlying sediment was transported downstream. Accelerometers were weighted to have a density comparable to streambed sediment (3.0 grams per cubic centimeter $\left[\mathrm{g} / \mathrm{cm}^{3}\right]$ ) so that they did not float. Reported measurement error of each axis' tilt ranged from about 5 to 22 degrees at a water temperature of $25^{\circ} \mathrm{C}$ as a function of logger orientation and water temperature. When the streambed was observed to be stable, small changes in tilt of less than 15 degrees were recorded by accelerometers; therefore, repeated changes in tilt that exceeded 15 degrees 


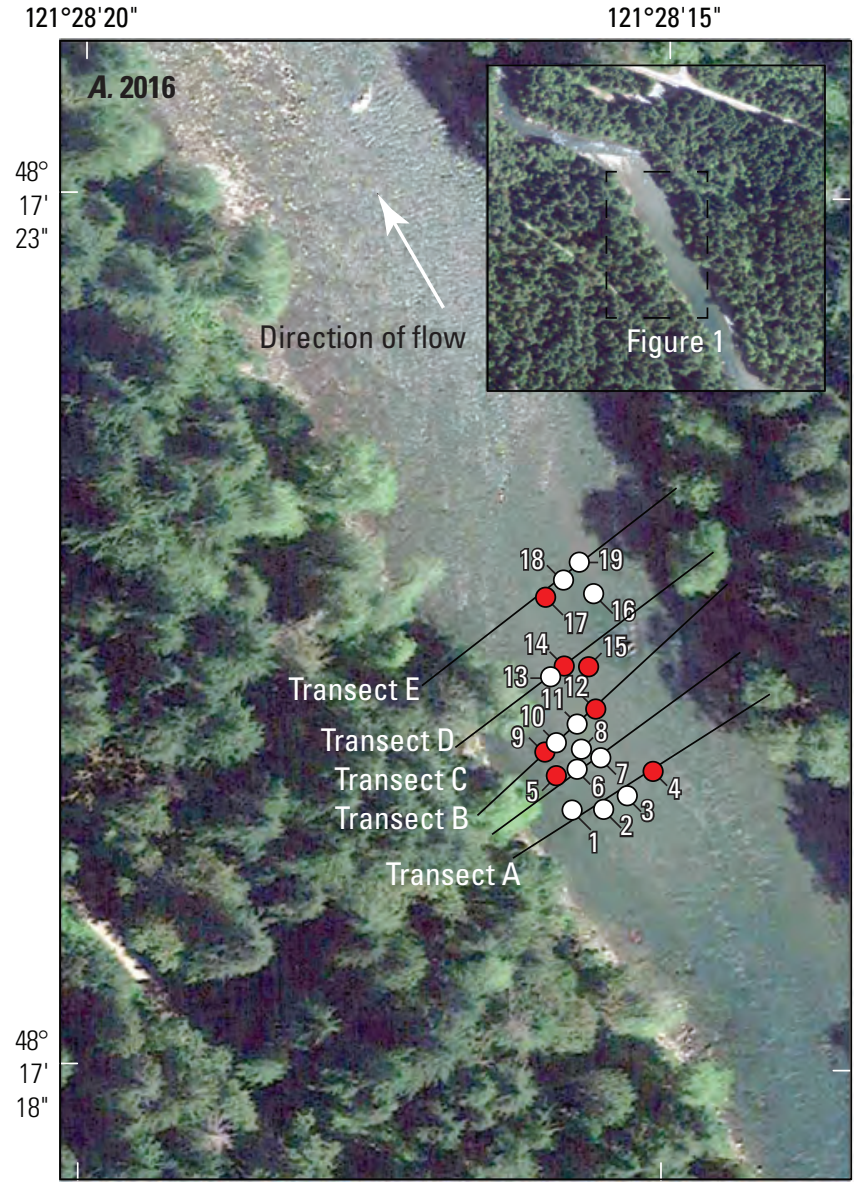

Base from U.S. Geological Survey National Elevation Dataset 30-meter digital elevation model showing land-surface elevations shaded at 2-meter intervals

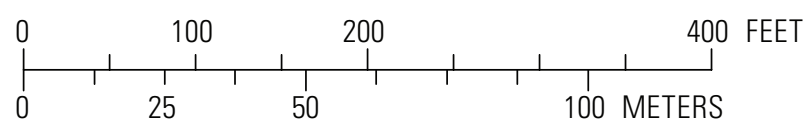

$121^{\circ} 28^{\prime} 20^{\prime \prime} \quad 121^{\circ} 28^{\prime} 15^{\prime \prime}$

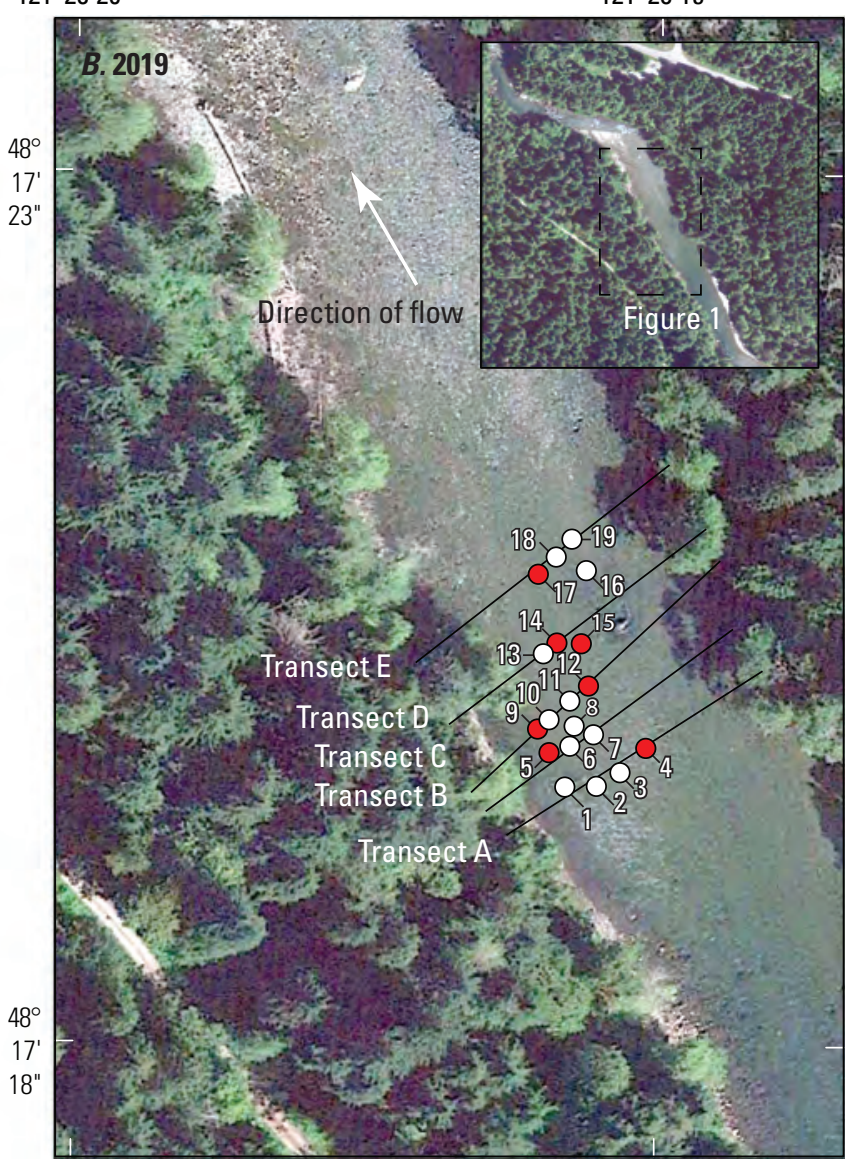

\section{EXPLANATION}

Accelerometer scour monitor

Not recovered

Recovered

Figure 2. Locations of accelerometer scour monitor deployments and transects at the upstream reach of the Sauk River near river mile 32.2, northwestern Washington. $(A) 2016$ imagery representative of pre-water year 2018 flood season channel and $(B) 2019$ imagery representative of post-water year 2018 flood season channel.

from the initial deployed orientation were inferred to be indicative of streambed scour at the depth of the accelerometer (Gendaszek and others, 2013).

ASMs were recovered and the post-flood season streambed elevation was surveyed in August 2018 when the streambed was accessible by wading. ASMs in the upstream reach were recovered after the flood season by finding the intersection of three circles created by stretching a measuring tape from each of the benchmarks recorded before the flood season. The intersection of the three circles was then searched using a PIT tag reader to locate the ASM to within several feet. ASMs in the downstream reach were located after the flood season using an RTK-GPS, which was subsequently searched with a PIT tag reader. The post-flood season elevation of the streambed was then surveyed using a Total Station and RTKGPS in the upstream and downstream reaches, respectively.
Net scour during the flood season was calculated as the difference between the pre- and post-flood season streambed surface. ASMs were then excavated using shovels and when the accelerometer was found in an undisturbed position, the level of the accelerometer was surveyed. Maximum scour was calculated as the difference between the pre-flood season streambed and the level of the post-flood season accelerometer. If the ASM was disturbed during excavation and recorded scour during its deployment, it was assumed that maximum scour reached at least the depth of the initial deployment level. Timeseries data about each accelerometer's three-dimensional orientation were downloaded from each ASM recovered in the field, analyzed for changes in orientation, and published as a ScienceBase data release (Gendaszek, 2020). Because accelerometers recorded small changes in tilt of less than 15 degrees when the streambed was observed to be stable, only 

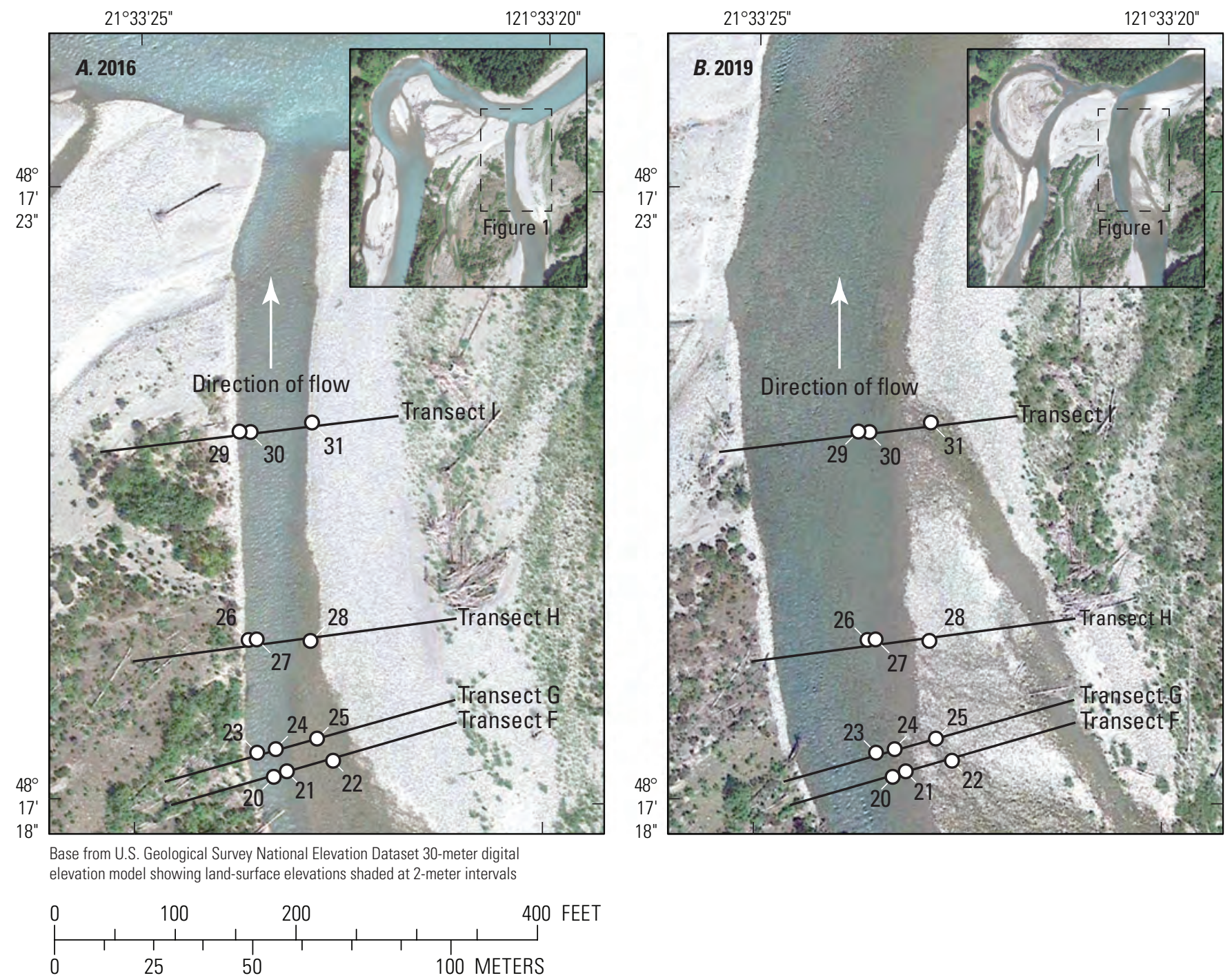

Figure 3. Aerial orthoimagery showing locations of accelerometer scour monitor deployments and transects at the downstream reach of the Sauk River near river mile 17.8, northwestern Washington. (A) 2016 imagery representative of pre-water year 2018 flood season channel and $(B) 2019$ imagery representative of post-water year 2018 flood season channel.

repeated changes in tilt exceeding 15 degrees from the initial deployed orientation were inferred to be indicative of accelerometer disturbance (Gendaszek and others, 2013). Changes in accelerometer orientation were analyzed with respect to discharge data measured at USGS streamgage 12186000 obtained from the National Water Information System (NWIS; U.S. Geological Survey, 2020). The magnitude and frequency of flood discharges was estimated for the Sauk River at the USGS streamgage 12186000 (Sauk River above White Chuck River) using 96 years of peak-discharge measurements from waters years 1918-1922 and 1929-2019. Annual peakdischarge analysis was performed using the USGS software program, Peak flow FreQuency (PeakFQ, ver. 7.3; Veilleux and others, 2014).

Geomorphic information, including the pre-flood season particle-size distribution and pre- and post-flood season channel cross sections, were surveyed at each of the nine transects where ASMs were installed. Particle-size distribution of surface sediment was estimated at each transect by Wolman pebble counts (Wolman, 1954) using gravelometers to measure the intermediate diameter of particles. The median $\left(\mathrm{D}_{50}\right)$ and 90th percentile $\left(D_{90}\right)$ grain size for each transect's pebble count was estimated and assigned to ASMs located within that transect. The location and elevation of the pre-deployment and post-deployment channel cross sections were measured before ASM deployment in August 2017 and after ASM retrieval in August 2018 in the upstream reach relative to a local network of benchmarks using a Total Station with a vertical accuracy of $0.03 \mathrm{~cm}$ and in the downstream reach using a real-time kinematic global positioning system (RTK-GPS) with a vertical accuracy of $2 \mathrm{~cm}$. At the downstream reach, swift current precluded wading part of each cross section during the postflood season. 


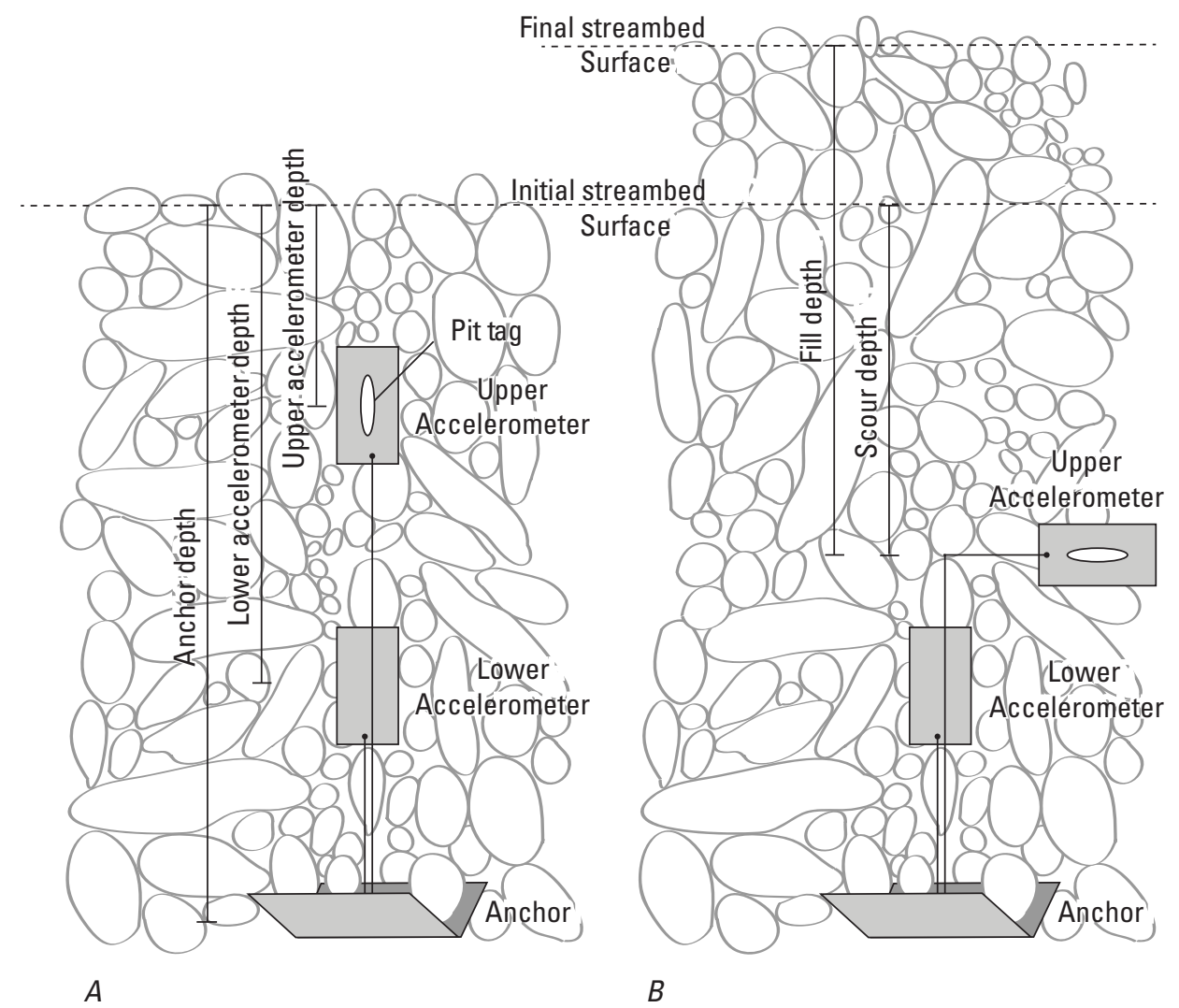

Figure 4. Accelerometer scour monitor deployment. $A$, Initial deployment of two accelerometers connected to an anchor using braided cable. $B$, Final orientation of accelerometers after flood season. Passive integrated transponders (PIT) tags were attached to the upper accelerometer to facilitate post-flood season retrieval. Adapted from Gendaszek and others (2013).

\section{Results}

\section{Hydrologic Regime}

Annual exceedance probabilities for the Sauk River were estimated for 96 years of peak discharge measurements (water years 1918-1922 and 1929-2019) measured at USGS streamgage 12186000. Discharge at the upstream reach, which is immediately downstream of this streamgage, is directly quantified by this streamgage, but the downstream reach includes additional discharge from the ungaged White Chuck River, Clear Creek, and other smaller tributaries in the intervening drainage basin. The 50-percent annual exceedance probability discharge (2-year recurrence interval discharge) at USGS streamgage 12186000 was estimated to be $271 \mathrm{~m}^{3} / \mathrm{s}$ $\left(9,560 \mathrm{ft}^{3} / \mathrm{s}\right)$ and the 10-percent annual exceedance probability discharge (10-year recurrence interval) was estimated to be $583 \mathrm{~m}^{3} / \mathrm{s}\left(20,580 \mathrm{ft}^{3} / \mathrm{s}\right)$; annual exceedance probability discharges at the downstream reach were not estimated but would have been higher because of the contributions of intervening discharges. Intervening annual exceedance probabilities estimated are presented in table 1 . In the 96 years of peak-discharge records, 82 peak discharges occurred between October and March with December accounting for 25 peak discharges, the most of any individual month. Whereas peak discharge events of up to $1,250 \mathrm{~m}^{3} / \mathrm{s}\left(44,000 \mathrm{ft}^{3} / \mathrm{s} ;<0.01\right.$ annual exceedance probability or 100 -year recurrence interval discharge) occurred between October and March resulted from high-intensity rainfall, the 13 annual peak discharge events measured between April and June resulted from snowmelt during the spring freshet. Unlike the short-lived, high-magnitude discharge peaks associated with autumn and winter storms, peak-flow events recorded during the spring freshet resulted from protracted, low-magnitude discharge that did not exceed the 50-percent annual exceedance probability discharge (2-year recurrence interval discharge). Annual peak discharge was recorded only during the spring freshet for years when no high-magnitude autumn and winter storms occurred.

During water year 2018, when scour monitors were deployed, two peak-flow events exceeding the 50-percent annual exceedance probability discharge as measured at the U.S. Geological Survey streamgage 12186000 occurred during October and November (fig. 5). Each of these events was characterized by two distinct peaks with a small peak preceding 
Table 1. Annual exceedance probabilities estimated for U.S. Geological Survey streamgage at Sauk River above White Chuck River, near Darrington, Washington (12186000).

$\left[\mathrm{m}^{3} / \mathrm{s}\right.$, cubic meters per second]

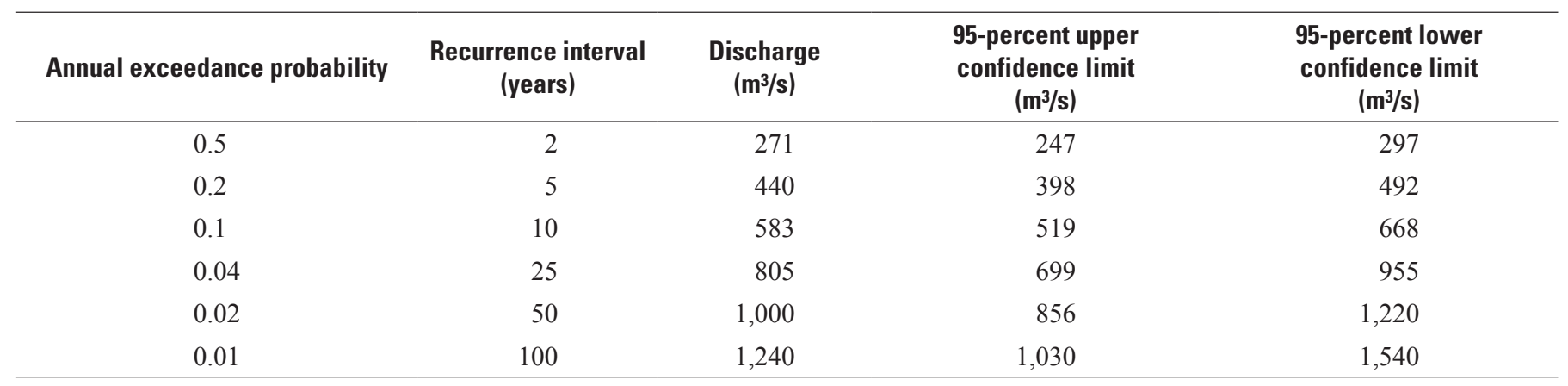

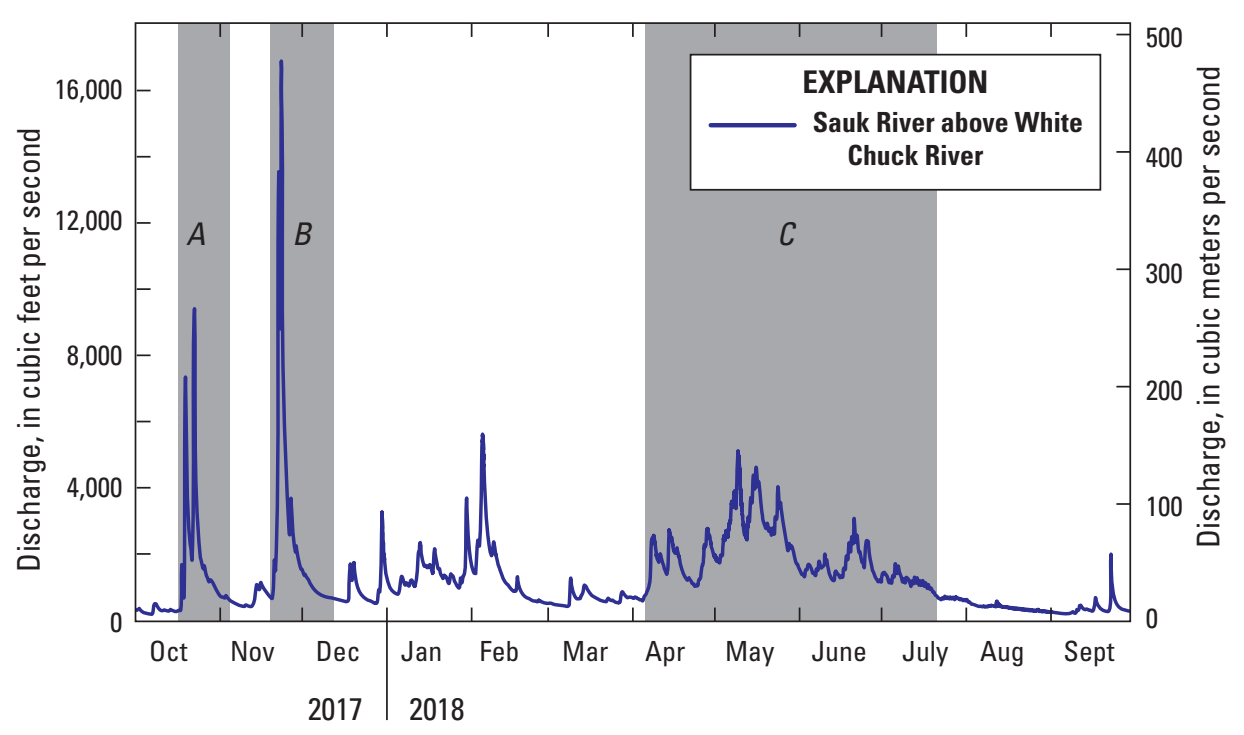

Figure 5. Graph showing discharge measured at U.S. Geological Survey streamgage 12186000, northwestern Washington, water year 2018. Peak discharge of $(A)$ October peak-flow event was $272 \mathrm{~m}^{3} / \mathrm{s}(9,610 \mathrm{ft} 3 / \mathrm{s})$ on October 22, 2017; $(B)$ November peak-flow event was $479 \mathrm{~m}^{3} / \mathrm{s}(16,900 \mathrm{ft} 3 / \mathrm{s})$ on November 23, 2017; and (C) April-July freshet was $145 \mathrm{~m}^{3} / \mathrm{s}$ $\left(5,130 \mathrm{ft}^{3} / \mathrm{s}\right)$ on May 9, 2018.

a large peak by several days. The small magnitude peak-flow event reached a peak discharge of $272 \mathrm{~m}^{3} / \mathrm{s}\left(9,610 \mathrm{ft}^{3} / \mathrm{s} ; 49\right.$ percent annual exceedance probability) on October 22, 2018, and was preceded by a small peak discharge of $211 \mathrm{~m}^{3} / \mathrm{s}$ $\left(7,440 \mathrm{ft}^{3} / \mathrm{s}\right) 3$ days prior (fig. $\left.5 A\right)$. A large magnitude peakflow event of $479 \mathrm{~m}^{3} / \mathrm{s}\left(16,900 \mathrm{ft}^{3} / \mathrm{s} ; 18\right.$ percent annual exceedance probability) occurred on November 23, 2018, and also was preceded by a small peak discharge of $385 \mathrm{~m}^{3} / \mathrm{s}(13,600$ $\mathrm{ft}^{3} / \mathrm{s}$ ) 1 day prior (fig. $5 B$ ). Discharge during the spring freshet peak reached $145 \mathrm{~m}^{3} / \mathrm{s}\left(5,130 \mathrm{ft}^{3} / \mathrm{s} ; 89\right.$ percent annual exceedance probability) on May 9, 2018 (fig. 5C) and no additional peak-flow events exceeding the 50-percent annual exceedance probability occurred during the remainder of the deployment of scour monitors.

\section{Geomorphic Changes during Water Year 2018}

During water year 2018, large-scale geomorphic changes occurred at the downstream reach (fig. 3) while the upstream reach remained largely stable (fig. 2). The downstream reach occupied a secondary channel of the Sauk River through a largely unvegetated floodplain. The left bank of the downstream reach was defined by the abrupt edge of an unvegetated terrace and the right bank was defined by the gradual edge of a gravel bar. During water year 2018, the left bank migrated from about $30 \mathrm{~m}$ at the downstream end of the reach as measured at transect I to about $15 \mathrm{~m}$ at the upstream end of the reach as measured at transect F (fig. 6). Up to $1.5 \mathrm{~m}$ of aggradation was measured on the right side of the channel 


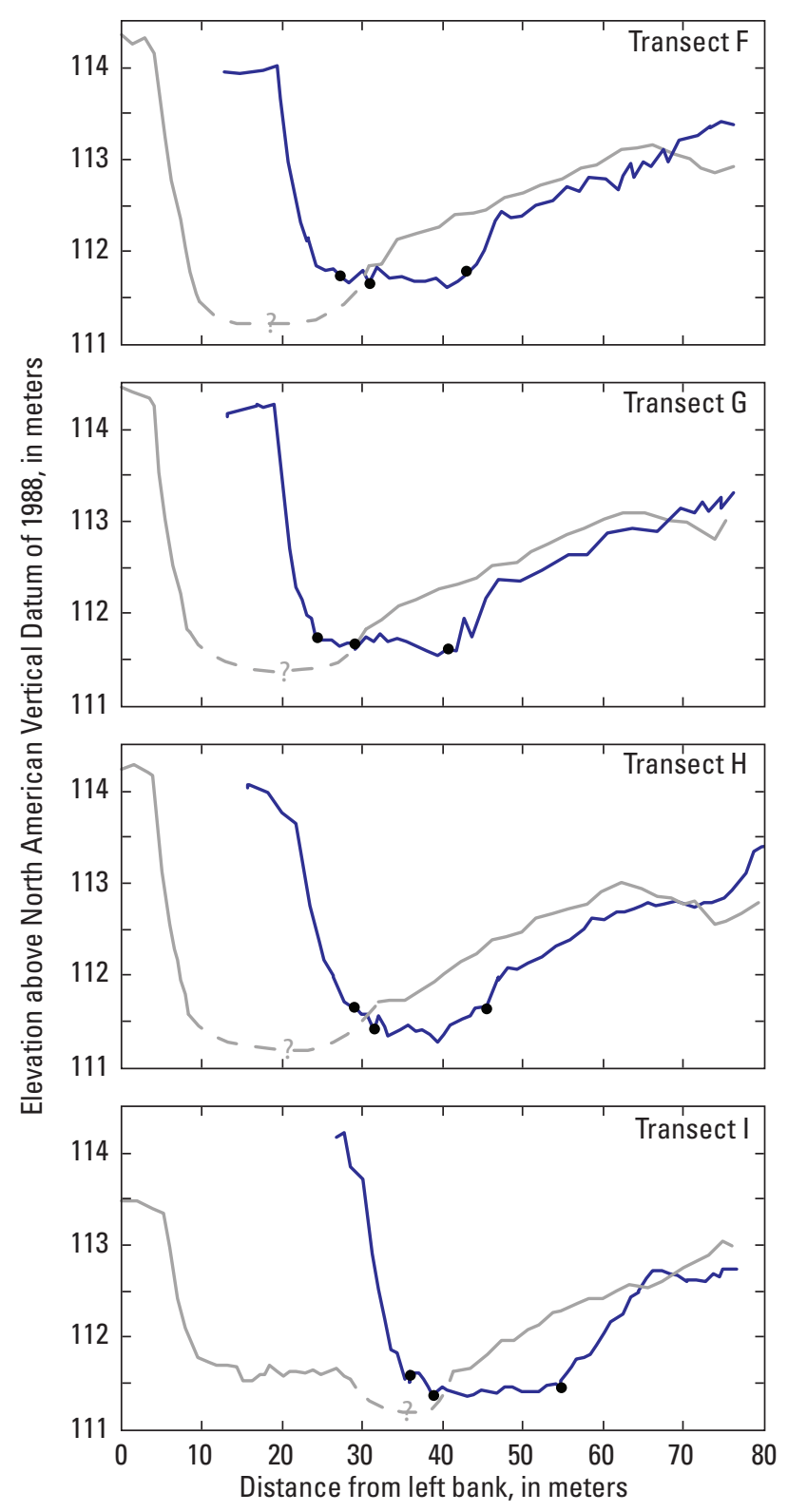

EXPLANATION

Water year 2018 flood season

Before

After

- Accelerometer scour monitor

Figure 6. Cross sections showing transects $\mathrm{F}-\mathrm{I}$ surveyed before and after water year 2018 flood season and locations of accelerometer scour monitors (ASMs) at the downstream reach of the Sauk River near river mile 17.8, northwestern Washington.

bar between the beginning and end of the water year 2018 . Conversely, the upstream reach occupied the main channel of the Sauk River and mature trees and vegetation stabilized its banks. Unlike the downstream reach, net changes to the channel of the upstream reach during water year 2018 were minimal with net changes of less than $10 \mathrm{~cm}$ in most of the channel except for aggradation of less than about $30 \mathrm{~cm}$ in a pool downstream of a large boulder measured within transect C. No lateral migration of the upstream reach occurred during water year 2018 (fig. 7).

\section{Accelerometer Scour Monitors}

ASMs were deployed in Chinook salmon spawning habitat at 19 locations across five transects (A-E) in the upstream reach (fig. 2) and at 12 locations across four transects (F-I) in the downstream reach (fig. 3). Each transect was instrumented with 3-4 ASMs, which were arranged laterally across the channel; if substrate prevented installation along the transect, ASMs were placed near, but not on the transect. Details of the ASM deployments including installation location and 


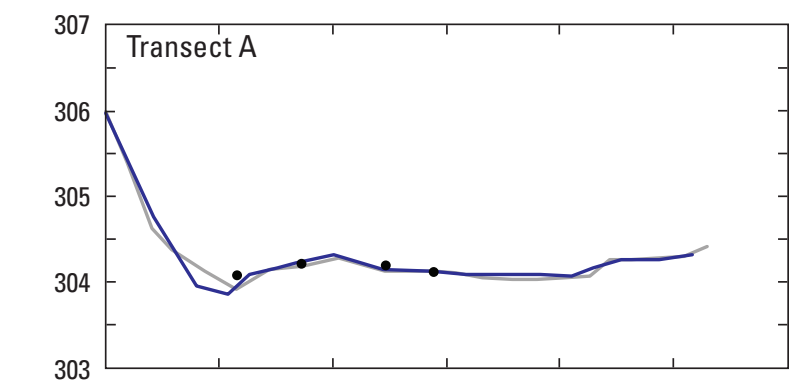

EXPLANATION

Water year 2018 flood season
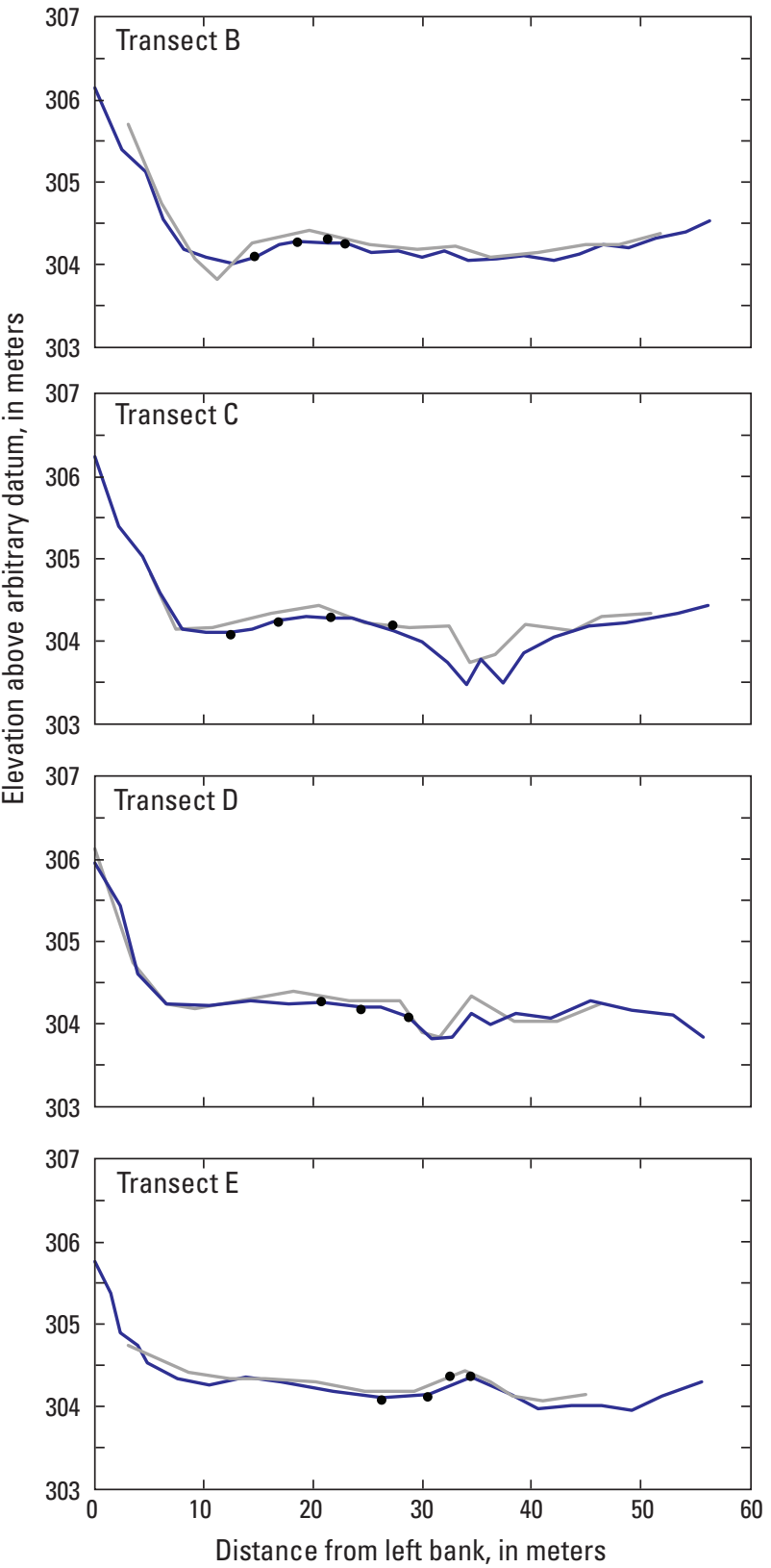

Figure 7. Cross sections showing transects A-E surveyed before and after water year 2018 flood season and locations of accelerometer scour monitors (ASMs) at the upstream reach of the Sauk River near river mile 32.2, northwestern Washington. 
depth, pre-flood season substrate characteristics, net change in streambed elevation, and maximum scour depth during water year 2018 flood season are presented in table 2.

Particle-size distributions of surficial sediment were estimated prior to water year 2018 along each transect in the upstream and downstream reaches. Median $\left(\mathrm{D}_{50}\right)$ particle size ranged from 38.9 to $47.9 \mathrm{~mm}$ in the upstream reach and ranged from 69.4 to $95.6 \mathrm{~mm}$ in the downstream reach. Dominant sediment size of surficial sediment ranged from gravel to cobbles within the study reaches, but was finer in the upstream reach than in the downstream reach. Large boulders in the upstream reach locally influenced streambed morphology. Net change in streambed elevation at the location of ASMs was determined by subtracting the pre-flood season streambed elevation measured during ASM recovery from the post-flood season streambed elevation measured during ASM deployment. In the upstream reach, net change in streambed elevation ranged from $-9 \mathrm{~cm}$ (scour) to $18 \mathrm{~cm}$ (fill) with a median of $-1 \mathrm{~cm}$, which is consistent with minimal net changes in the cross section during water year 2018 flood season (fig. 7). Net change in streambed elevation during the flood season in the downstream reach ranged from 18 to $89 \mathrm{~cm}$ (fill) with a median of $67 \mathrm{~cm}$ (fig. 6). This aggradation resulted in deposition of a gravel bar over the previous channel in which the ASMs were deployed.

Floods during water year 2018 resulted in widespread streambed scour and sediment transport in the upstream and downstream reaches. An attempt to recover deployed ASMs was made after the flood season by triangulating from monuments in the upstream reach using a measuring tape and RTK-GPS in the downstream reach. A PIT tag reader was then used to confirm the location of the deployed ASM, which was subsequently excavated using shovels. Following the water year 2018 flood season, 7 of the 19 ASMs deployed in the upstream reach were recovered and none of the 12 ASMs deployed in the downstream reach were recovered. The upper accelerometers of all seven recovered ASMs in the upstream reach recorded motion during two peak-flow events in October $\left(272 \mathrm{~m}^{3} / \mathrm{s} ; 9,610 \mathrm{ft}^{3} / \mathrm{s}\right)$ and November $2017(749 \mathrm{~m} / \mathrm{s} ; 16,900$ $\mathrm{ft}^{3} / \mathrm{s}$ ) and the lower accelerometers of two of the seven recovered ASMs also recorded subsequent movement. The streambed at the location of ASMs that were not recovered was excavated to the installation depth of its anchor to determine that the ASM was not recovered and scour was assumed to have progressed to the at least depth of the anchor.

Initial scour at most of the ASMs occurred during the rising limb of the October 2017 peak-flow event, which was followed by stabilization during the deposition of sediment and remobilization and additional scour during the rising limb of the November 2017 peak-flow event (table 3). Scour recorded by the upper accelerometer of six of the seven recovered ASMs initiated before the peak of the October peak-flow event at discharges at or exceeding $204 \mathrm{~m}^{3} / \mathrm{s}\left(7,210 \mathrm{ft}^{3} / \mathrm{s}\right)$. As discharge decreased during the falling limb of the October peakflow event's hydrograph, the six ASMs that recorded scour became stable, which was interpreted to be the deposition of fill consistent with Gendaszek and others (2013; fig. 8). Scour was next recorded during the rising limb of larger magnitude November 2017 peak-flow event when all six accelerometer scour monitors that initially scoured during the October 2017 peak-flow event became mobile again indicating that scour progressed below the depth of the fill that deposited at the end of the peak-flow event (fig. 9). Progressive scour at the lower accelerometer scour monitor was recorded at two of the accelerometer scour monitors that initially scoured in October (ASM-9 and ASM-14). In addition, a seventh ASM that had remained unscoured during the October 2017 peak-flow event was mobilized during the November 2017 peak-flow event at a discharge of $270 \mathrm{~m}^{3} / \mathrm{s}\left(9,550 \mathrm{ft}^{3} / \mathrm{s}\right)$. Scour was assumed to have progressed below the depth of the anchor of the remaining 12 ASMs that were not recovered at the upstream reach and all 12 ASMs that were not recovered at the downstream reach. 
Table 2. Accelerometer scour monitor site characteristics, northwestern Washington, water year 2018.

[Abbreviations: $\mathrm{cm}$, centimeter; mm, millimeter; - , not applicable]

\begin{tabular}{|c|c|c|c|c|c|c|c|}
\hline \multirow[b]{2}{*}{$\begin{array}{l}\text { Accelerometer } \\
\text { scour monitor }\end{array}$} & \multirow[b]{2}{*}{ Transect } & \multirow{2}{*}{$\begin{array}{l}\text { Particle size } \\
\mathrm{D}_{50} \\
\text { Median } \\
\text { (mm) }\end{array}$} & \multirow{2}{*}{$\begin{array}{c}D_{90} \\
90 \text { th } \\
\text { percentile } \\
(\mathrm{mm})\end{array}$} & \multicolumn{2}{|c|}{ Deployed accelerometer depth } & \multirow{2}{*}{$\begin{array}{c}\text { Net change in } \\
\text { streambed } \\
\text { elevation } \\
\text { (water year 2018) } \\
\text { (cm) } \\
\end{array}$} & \multirow[b]{2}{*}{$\begin{array}{l}\text { Maximum } \\
\text { scour dept| } \\
\text { (cm) }\end{array}$} \\
\hline & & & & $\begin{array}{l}\text { Upper } \\
\text { (cm) }\end{array}$ & $\begin{array}{l}\text { Lower } \\
\text { (cm) }\end{array}$ & & \\
\hline \multicolumn{8}{|c|}{ Upstream reach (fig. 2) } \\
\hline ASM-1 & A & 38.9 & 78.7 & 9 & 24 & -6 & - \\
\hline ASM-2 & A & 38.9 & 78.7 & 15 & 30 & -1 & - \\
\hline ASM-3 & A & 38.9 & 78.7 & 12 & 27 & -1 & - \\
\hline ASM-4 & A & 38.9 & 78.7 & 15 & 30 & 1 & -18 \\
\hline ASM-5 & $\mathrm{B}$ & 42.7 & 78.7 & 12 & 25 & -7 & -23 \\
\hline ASM-6 & $\mathrm{B}$ & 42.7 & 78.7 & 13 & 28 & -4 & - \\
\hline ASM-7 & $\mathrm{B}$ & 42.7 & 78.7 & 10 & 25 & -7 & - \\
\hline ASM-8 & $\mathrm{B}$ & 42.7 & 78.7 & 8 & 23 & 4 & - \\
\hline ASM-9 & $\mathrm{C}$ & 47.9 & 82.2 & 12 & 27 & -2 & -28 \\
\hline ASM-10 & $\mathrm{C}$ & 47.9 & 82.2 & 10 & 25 & -2 & - \\
\hline ASM-11 & $\mathrm{C}$ & 47.9 & 82.2 & 13 & 28 & 4 & - \\
\hline ASM-12 & $\mathrm{C}$ & 47.9 & 82.2 & 16 & 31 & 3 & -18 \\
\hline ASM-13 & $\mathrm{D}$ & 46.1 & 92.5 & 11 & 26 & 0 & - \\
\hline ASM-14 & $\mathrm{D}$ & 46.1 & 92.5 & 15 & 30 & 2 & $\leq-30$ \\
\hline ASM-15 & $\mathrm{D}$ & 46.1 & 92.5 & 9 & 24 & 1 & -18 \\
\hline ASM-16 & $\mathrm{E}$ & 47.0 & 89.1 & 14 & 29 & -5 & - \\
\hline ASM-17 & $\mathrm{E}$ & 47.0 & 89.1 & 12 & 27 & 18 & $\leq-12$ \\
\hline ASM-18 & $\mathrm{E}$ & 47.0 & 89.1 & 15 & 30 & -5 & - \\
\hline ASM-19 & E & 47.0 & 89.1 & 15 & 30 & -9 & - \\
\hline \multicolumn{8}{|c|}{ Downstream reach (fig. 3) } \\
\hline ASM-20 & $\mathrm{F}$ & 95.6 & 153.0 & 8 & - & - & - \\
\hline ASM-21 & $\mathrm{F}$ & 95.6 & 153.0 & 13 & - & 18 & - \\
\hline ASM-22 & $\mathrm{F}$ & 95.6 & 153.0 & 12 & 27 & 72 & - \\
\hline ASM-23 & G & 75.5 & 145.0 & 15 & 30 & - & - \\
\hline ASM-24 & G & 75.5 & 145.0 & 15 & 30 & - & - \\
\hline ASM-25 & G & 75.5 & 145.0 & 15 & 30 & 61 & - \\
\hline ASM-26 & $\mathrm{H}$ & 69.4 & 147.3 & 4 & 19 & - & - \\
\hline ASM-27 & $\mathrm{H}$ & 69.4 & 147.3 & 17 & 32 & 28 & - \\
\hline ASM-28 & $\mathrm{H}$ & 69.4 & 147.3 & 14 & 29 & 79 & - \\
\hline ASM-29 & I & 76.7 & 140.4 & 12 & 27 & - & - \\
\hline ASM-30 & I & 76.7 & 140.4 & 8 & - & - & - \\
\hline ASM-31 & I & 76.7 & 140.4 & 8 & 23 & 89 & - \\
\hline
\end{tabular}

Accelerometers were not recovered at these locations despite excavating to the deployed depths of the monitors and searching for the PIT tag integrated into the monitor. 
Table 3. Temporal record of scour recorded and geomorphic data for accelerometer scour monitors deployed, northwestern Washington, water year 2018.

[Date time upper accelerometer movement: Month/day/year 24-hour time. Abbreviations: ASM, accelerometer scour monitor; PDT, Pacific Daylight Time; PST, Pacific Standard Time; $\mathrm{m}^{3} / \mathrm{s}$, cubic meters per second; - , not applicable]

\begin{tabular}{|c|c|c|c|c|c|c|}
\hline $\begin{array}{l}\text { Accelerometer } \\
\text { scour monitor }\end{array}$ & Transect & $\begin{array}{l}\text { Recovered } \\
\text { Status }\end{array}$ & $\begin{array}{l}\text { Date/time of upper accel- } \\
\text { erometer movement }\end{array}$ & $\begin{array}{c}\text { Discharge at } \\
\text { streamgage } \\
12186000 \text { at } \\
\text { time of upper } \\
\text { accelerometer } \\
\text { movement } \\
\left(\mathrm{m}^{3} / \mathrm{s}\right)\end{array}$ & $\begin{array}{l}\text { Date/time of lower ac- } \\
\text { celerometer movement }\end{array}$ & $\begin{array}{c}\text { Discharge at } \\
\text { streamgage } \\
12186000 \text { at } \\
\text { time of lower } \\
\text { accelerometer } \\
\text { movement } \\
\left(\mathrm{m}^{3} / \mathrm{s}\right)\end{array}$ \\
\hline \multicolumn{7}{|c|}{ Upstream reach (fig. 2) } \\
\hline ASM-1 & A & $\mathrm{N}$ & - & - & - & - \\
\hline ASM-2 & $\mathrm{A}$ & $\mathrm{N}$ & - & - & - & - \\
\hline ASM-3 & $\mathrm{A}$ & $\mathrm{N}$ & - & - & - & - \\
\hline ASM-4 & $\mathrm{A}$ & $\mathrm{Y}$ & 10/19/2017 0030 PDT & 206 & - & - \\
\hline ASM-5 & B & $\mathrm{Y}$ & 10/22/2017 0430 PDT & 256 & - & - \\
\hline ASM-6 & B & $\mathrm{N}$ & - & - & - & - \\
\hline ASM-7 & B & $\mathrm{N}$ & - & - & - & - \\
\hline ASM-8 & B & $\mathrm{N}$ & - & - & - & - \\
\hline ASM-9 & $\mathrm{C}$ & $\mathrm{Y}$ & 10/22/2017 0545 PDT & 265 & 11/23/2017 0815 PST & 405 \\
\hline ASM-10 & $\mathrm{C}$ & $\mathrm{N}$ & - & - & - & - \\
\hline ASM-11 & $\mathrm{C}$ & $\mathrm{N}$ & - & - & - & - \\
\hline ASM-12 & $\mathrm{C}$ & $\mathrm{Y}$ & 10/19/2017 0345 PDT & 204 & - & - \\
\hline ASM-13 & $\mathrm{D}$ & $\mathrm{N}$ & - & - & - & - \\
\hline ASM-14 & $\mathrm{D}$ & $\mathrm{Y}$ & 10/19/2017 0345 PDT & 204 & 11/22/2017 0415 PST & 354 \\
\hline ASM-15 & $\mathrm{D}$ & $\mathrm{Y}$ & 10/22/2017 1000 PDT & 268 & - & - \\
\hline ASM-16 & $\mathrm{E}$ & $\mathrm{N}$ & - & - & - & - \\
\hline ASM-17 & $\mathrm{E}$ & $\mathrm{Y}$ & $11 / 23 / 20170215$ PST & 270 & - & - \\
\hline ASM-18 & $\mathrm{E}$ & $\mathrm{N}$ & - & - & - & - \\
\hline ASM-19 & E & $\mathrm{N}$ & - & - & - & - \\
\hline \multicolumn{7}{|c|}{ Downstream reach (fig. 3) } \\
\hline ASM-20 & F & $\mathrm{N}$ & - & - & - & - \\
\hline ASM-21 & $\mathrm{F}$ & $\mathrm{N}$ & - & - & - & - \\
\hline ASM-22 & $\mathrm{F}$ & $\mathrm{N}$ & - & - & - & - \\
\hline ASM-23 & G & $\mathrm{N}$ & - & - & - & - \\
\hline ASM-24 & G & $\mathrm{N}$ & - & - & - & - \\
\hline ASM-25 & G & $\mathrm{N}$ & - & - & - & - \\
\hline ASM-26 & $\mathrm{H}$ & $\mathrm{N}$ & - & - & - & - \\
\hline ASM-27 & $\mathrm{H}$ & $\mathrm{N}$ & - & - & - & - \\
\hline ASM-28 & $\mathrm{H}$ & $\mathrm{N}$ & - & - & - & - \\
\hline ASM-29 & I & $\mathrm{N}$ & - & - & - & - \\
\hline ASM-30 & I & $\mathrm{N}$ & - & - & - & - \\
\hline ASM-31 & $\mathrm{I}$ & $\mathrm{N}$ & - & - & - & - \\
\hline
\end{tabular}



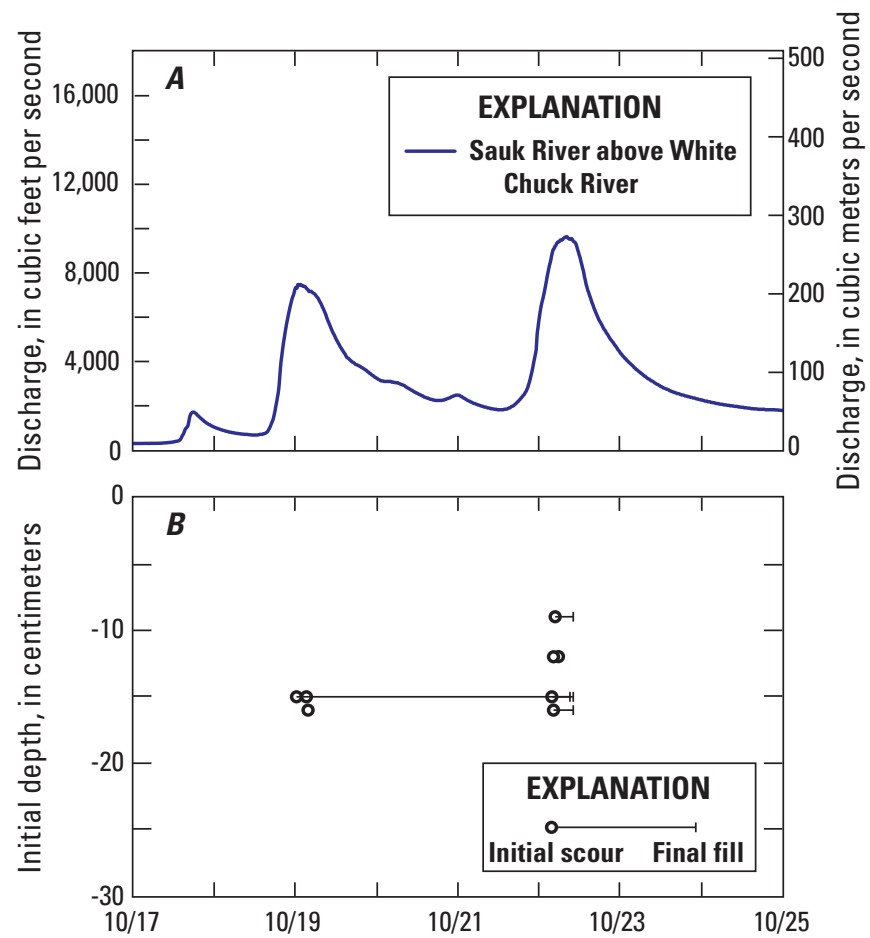

Figure 8. Graphs showing discharge and duration of initial scour and final fill during October 2017 peak-flow event, northwestern Washington. A. Discharge measured during the October 2017 peak-flow event at the Sauk River above White Chuck River (U.S. Geological Survey streamgage 12186000). B. When initial scour and final fill occurred during the October 2017 peak-flow event versus the initial accelerometer scour monitor installation depth. Dates are in month/day format.

\section{Discussion}

Between fertilization and emergence as fry from streambed gravels, incubating salmon embryos are vulnerable to scour as streambed gravels mobilize during floods. In western Washington, the incubation period corresponds with the autumn and winter flood season when sediment-mobilizing discharges most frequently occur. In the Sauk River, the average spawning date of Chinook salmon is September 15 (standard deviation $=9.1$ days; Beechie and others, 2006). The amount of time that salmon spend within streambed gravels before emerging as fry depends in large part on water temperature, with the average incubation period for Chinook salmon lasting about 1,000 accumulated thermal units measured in Celsius (Connor and others, 2003; Geist and others, 2006). One accumulated thermal unit is equal to one degree Celsius for one day and is used, in this case, to describe the cumulative effect of water temperature on incubating salmon embryos. As calculated from water temperature records measured at USGS streamgage 12186000 during water years 2018-2020, this threshold was reached in the Sauk River by mid-March. These

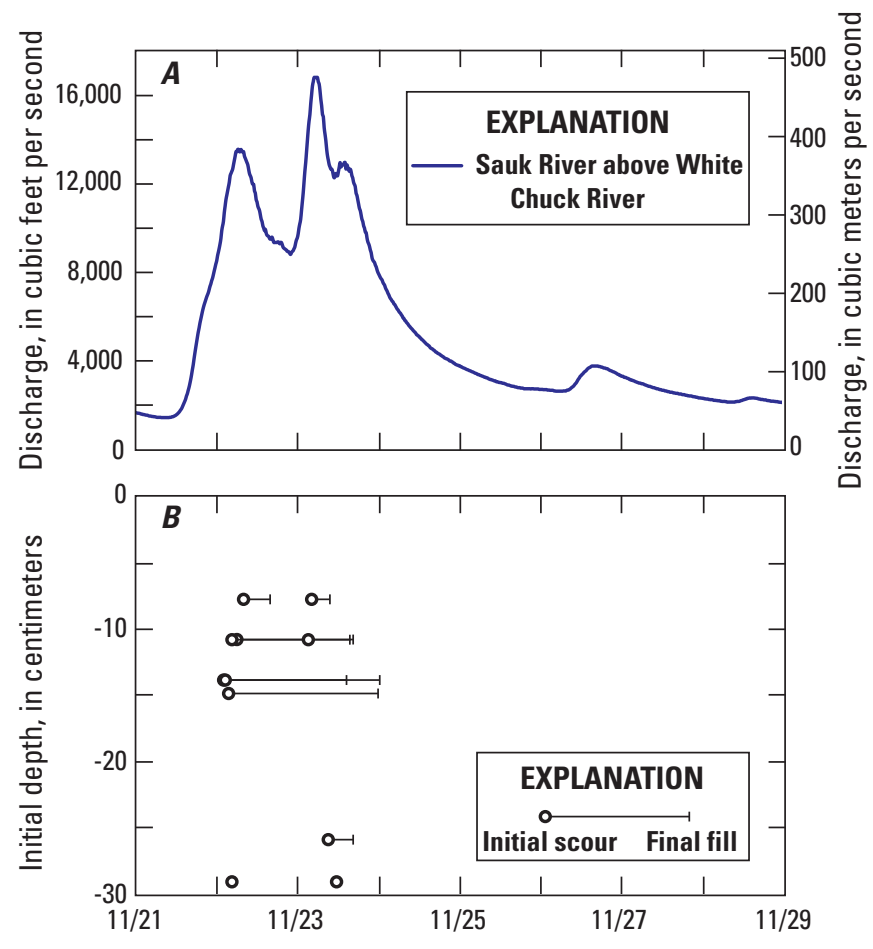

Figure 9. Discharge and duration of initial scour and final fill during November 2017 peak-flow event, northwestern Washington. A, Discharge measured during the November 2017 peak-flow event at the Sauk River above White Chuck River (U.S. Geological Survey streamgage 12186000). B, When initial scour and final fill occurred during the November 2017 peak-flow event versus the initial accelerometer scour monitor installation depth. Dates are in month/day format.

data indicate that developing Chinook embryos in the Sauk River remain vulnerable to streambed scour for the duration of the October-March period that accounts for most of the Sauk River's peak-flow events. By the onset of the spring freshet, Chinook fry have emerged and are no longer vulnerable to scour although the incubation period of other anadromous salmonids like steelhead trout (O. mykiss) do overlap with the March- June freshet.

Hydrologic conditions when streambed scour progressed to the depth of incubating salmon embryos were assessed during two peak-flow events in the Sauk River during water year 2018. Both peak-flow events occurred during the Chinook incubation period with peak discharge of the first event reaching $272 \mathrm{~m}^{3} / \mathrm{s}\left(9,610 \mathrm{ft}^{3} / \mathrm{s} ; 49\right.$ percent annual exceedance probability) on October 22, 2018, and the peak discharge of the second event reaching $479 \mathrm{~m}^{3} / \mathrm{s}\left(16,900 \mathrm{ft}^{3} / \mathrm{s} ; 18\right.$ percent annual exceedance probability) on November 23, 2018. Because only 7 of 19 ASMs deployed in the upstream reach were recovered and none of the 12 deployed in the downstream reach were recovered, the timing and spatial extent of scour recorded by ASMs was incomplete. Nevertheless, the recovered ASMs and the spatial distribution of unrecovered ASMs provide bounds 
on the hydrologic and geomorphic conditions under which scour occurs at the level of incubating salmon embryos in the Sauk River.

The minimum discharge at which scour progressed to the upper accelerometer was $204 \mathrm{~m}^{3} / \mathrm{s}\left(7,210 \mathrm{ft}^{3} / \mathrm{s}\right)$ during the October peak-flow event as measured at USGS streamgage 12186000 , which represents a 0.7 annual exceedance probability (1.4-year recurrence interval). Scour was measured during the rising limb of the October peak-flow event hydrograph at six of the seven ASMs that were recovered from the upstream reach (fig. 8), which is consistent with previous deployments of ASMs (Gendaszek and others, 2013, 2018, 2020) and electronic scour monitors (DeVries and others, 2001). Three of the six ASMs that recorded scour during the October peak-flow event initially recorded scour during the low-magnitude peak on October 19; the other three initially recorded scour during the second high-magnitude peak on October 22. Several ASMs that recorded scour during the October 19 peak-flow event were either subsequently buried and immobilized by fill before being scoured again during the October 22 peak. Initiation of scour during the rising limb of the peak-flow hydrograph is consistent with increased availability of streambed sediment that can be mobilized prior to the peak of the hydrograph relative to the receding limb of the peak-flow hydrograph (Mao, 2012). The timing of scour that was recorded by unrecovered scour monitors, however, is unknown, and therefore the minimum discharge at which scour was recorded at ASM-12 and ASM-14 $\left(204 \mathrm{~m}^{3} / \mathrm{s} ; 7,210 \mathrm{ft}^{3} / \mathrm{s}\right)$ may be regarded as an upper bound on the minimum discharge at which scour progressed to the top of salmon egg pockets. As discharge increased, the spatial extent and depth of scour increased commensurately.

Peak discharge during the November peak-flow event $\left(479 \mathrm{~m}^{3} / \mathrm{s} ; 16,900 \mathrm{ft}^{3} / \mathrm{s}\right)$ was nearly double the peak discharge of the October peak-flow event $\left(272 \mathrm{~m}^{3} / \mathrm{s} ; 9,610 \mathrm{ft}^{3} / \mathrm{s}\right)$ resulting in remobilization of the upper ASMs that recorded scour during the October peak-flow event. As during the October peak-flow event, initial scour during the November peak-flow event occurred during the rising limb of the peak-flow hydrograph and individual ASMs recorded intermittent periods of scour and fill (fig. 9). At two of the monitor locations (ASM-9 and ASM-14), lower accelerometers, which remained stable and did not record scour during the October peak-flow event, recorded scour for the first time during the rising limb of the November peak-flow event. At ASM-9, for example, the upper accelerometer, which was installed to a depth of $12 \mathrm{~cm}$ was mobilized during the rising limb of the October peak-flow event's hydrograph, but the lower accelerometer was not scoured (fig. 10), suggesting that egg pockets at this depth would have been partially, but not completely, impacted by the October peak-flow event. The orientation of the upper accelerometer of ASM-9 stabilized following the October peakflow event, indicating that fill was deposited over ASM-9. The upper accelerometer of ASM-9 was scoured again during the rising limb of the first peak of the November peak-flow hydrograph and recorded a changing orientation throughout the November peak-flow event, indicating that the ASM-9 was
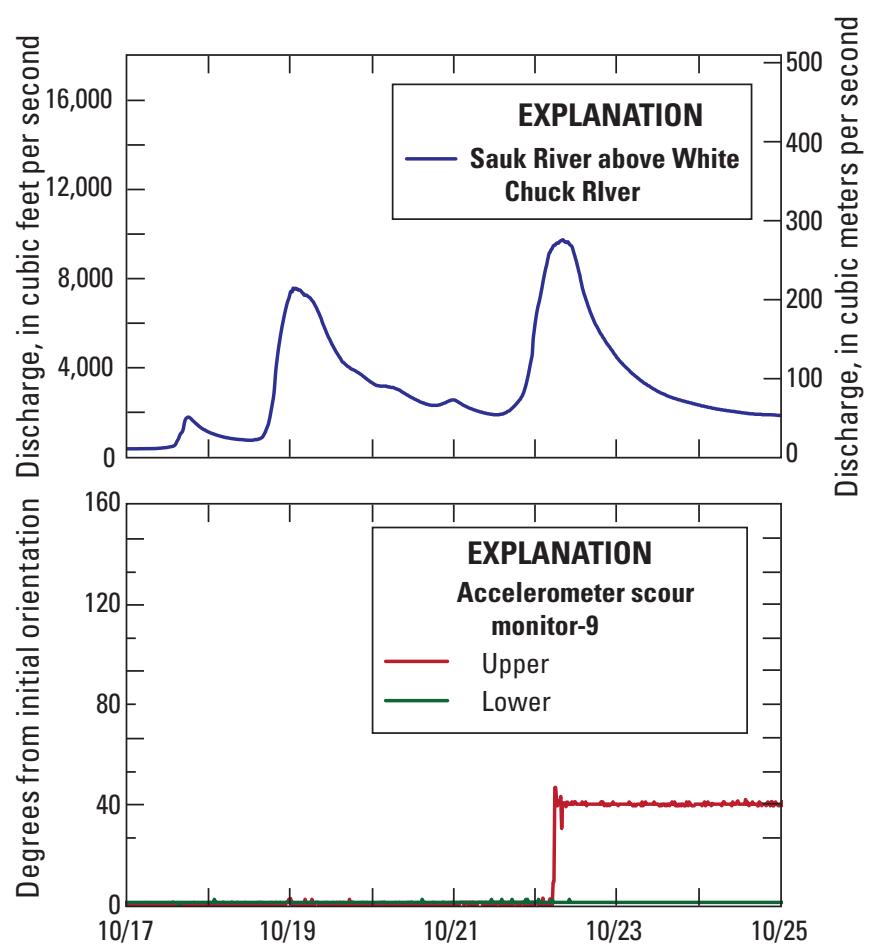

Figure 10. Tilt recorded by upper and lower accelerometers of ASM-9 during the October peak-flow event, northwestern Washington. Dates are in month/day format.

above the streambed (fig. 11). As discharge increased toward the peak of the November event, the lower accelerometer also was mobilized, indicating that scour had progressed to the depth of the lower accelerometer at ASM-9. Although only two of the ASMs recorded progression of scour to the depth of the lower accelerometer, remobilization of upper accelerometers that recorded scour during the October peak-flow event at other locations indicates widespread remobilization of the streambed at the level of incubating salmon eggs during the November peak-flow event to at least the depth that was reached in October. At the locations of ASM-9 and ASM-14, scour progressed below the entire depth of the Chinook egg pocket.

Unrecovered scour monitors were scoured below the $50-\mathrm{cm}$ depth of the anchor indicating extensive, deep scour occurred throughout both study reaches but the timing of that scour is unknown. Under equilibrium transport (sediment transport into a reach equals transport out of a reach), maximum scour depth is limited to twice the $\mathrm{D}_{90}\left(2 \mathrm{D}_{90}\right.$; DeVries and others, 2001; DeVries, 2002). Maximum scour at the seven recovered ASM locations did not exceed $2 \mathrm{D}_{90}$, but scour below the $50-\mathrm{cm}$ anchor at unrecovered ASMs in the upstream and downstream reaches was up to six times $D_{90}$. Measured scour suggests that imbalances in sediment transport rates within the study reaches may have led to maximum scour depths that exceeded $2 \mathrm{D}_{90}$, the maximum scour depth associated with equilibrium transport. Although scour depths 

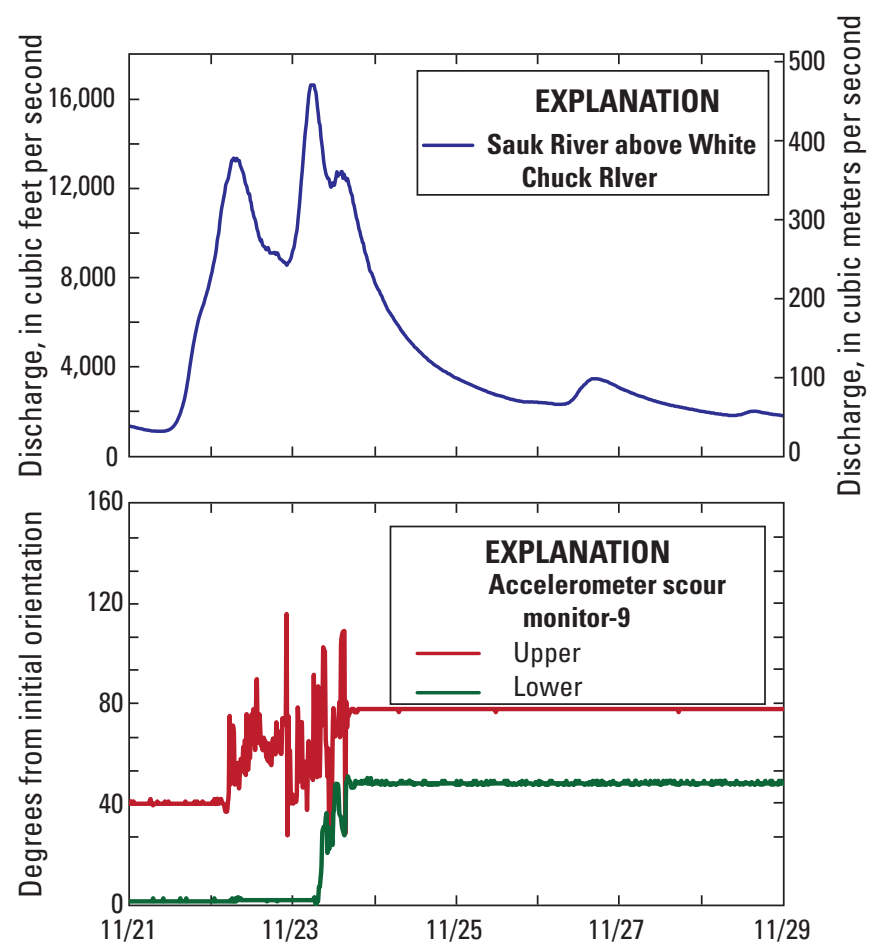

Figure 11. Tilt recorded by upper and lower accelerometers of ASM-9 during the November peak-flow event, northwestern Washington. Dates are in month/day format.

suggestive of this imbalance occurred in both study reaches, deep scour exceeding a depth of $2 \mathrm{D}_{90}$ occurred at each ASM location within the downstream reach, which occupied a braided, largely unvegetated channel that is susceptible to large-scale geomorphic changes including channel avulsions (DeVries and Aldrich, 2015). During sediment transporting peak-flow events, the quantity of water and sediment conveyed by different channels within the braided section of the Sauk River may change, resulting in local erosion and deposition of sediment and planform channel changes. During water year 2018 flood season, erosion of an unvegetated bank on left side and deposition of gravel bar on the right side of the channel resulted in a net aggradation of up to $1.5 \mathrm{~m}$ within the former channel and a leftward shift of the channel. Prior to the water year 2018 flood season, the downstream reach was within a secondary channel, but after the flood season it became the primary channel conveying most of the water through the reach. Because no scour monitors were recovered from the downstream reach, the streambed was likely mobilized below the 50-cm depth of the ASM anchor before sediment was deposited. The timing of streambed scour and fill was not well constrained within the downstream reach because none of the 12 deployed ASMs were recovered; however, it was assumed that they were scoured during either the October or November peak-flow event. In addition, aggradation of sediment within this reach could have prevented emergence of fry.

\section{Summary}

Accelerometer scour monitors (ASMs) deployed in two reaches of the Sauk River recorded streambed scour at the depth of incubating salmon embryos during water year 2018 . Scour occurred during two peak-flow events in October and November 2017 when discharge exceeded $204 \mathrm{~m}^{3} / \mathrm{s}$ (7,210 $\mathrm{ft}^{3} / \mathrm{s}$ ) at U.S. Geological Survey streamgage 12186000, which represents a 0.7 annual exceedance probability (1.4-year recurrence interval). Scour was intermittently recorded at all recovered ASMs with intervening periods of fill deposition characterized by a stable orientation of the accelerometers. At two ASMs, scour progressed from the top to the bottom of the accelerometer suggesting that the entire depth of the egg pocket would have been scoured during the peak-flow events. Most deployed ASMs, however, were not recovered because scour exceeded their anchor depth and therefore scour may have initiated at a lower discharge. Widespread scour that exceeded a depth of twice the $\mathrm{D}_{90}$ at the ASMs that were not recovered suggests that sediment transport imbalances in which export of sediment out of the scour monitor reach exceeded sediment input. At the downstream reach, large-scale geomorphic changes may have contributed to this imbalance where the study reach, which was a secondary channel before the flood season, became the primary channel after the flood season conveying most of the Sauk River's discharge. This shift was accompanied by erosion of up to 15 meters of an unvegetated island on the left side of the channel and deposition of up to 1.5 meters of sediment at the location of the former channel. Collectively, these data inform fisheries managers about the hydrologic conditions when scour at the depth of salmon redd pockets occurs in different geomorphic settings so that they are able to understand how current and projected changes in flood hydrology may impact restoration efforts of salmon fisheries.

\section{Acknowledgements}

The study presented in this report was jointly funded by the U.S. Geological Survey using Cooperative Matching Funds (CMF) and the Sauk-Suiattle Indian Tribe. The author would like to thank staff from the Sauk-Suiattle Indian Tribe Natural Resources Department for help selecting study sites and deploying and retrieving Accelerometer Scour Monitors. 


\section{References Cited}

Beechie, T., Buhle, E., Ruckelshaus, M., Fullerton, A., and Holsinger, L., 2006, Hydrologic regime and the conservation of salmon life history diversity: Biological Conservation, v. 130, no. 4, p. 560-572, accessed September 26, 2020.

Connor, W.P., Piston, C.E., and Garcia, A.P., 2003, Temperature during Incubation as One Factor Affecting the Distribution of Snake River Fall Chinook Salmon Spawning Areas: Transactions of the American Fisheries Society, v. 132, no. 6, p. 1236-1243, accessed September 20, 2020.

Cunjak, R.A., Prowse, T.D., and Parrish, D.L., 1998, Atlantic salmon ( Salmo salar ) in winter- "the season of parr discontent"?: Canadian Journal of Fisheries and Aquatic Sciences, v. 55, S1, p. 161-180, accessed September 26, 2020.

DeVries, P., 1997, Riverine salmonid egg burial depthsReview of published data and implications for scour studies: Canadian Journal of Fisheries and Aquatic Sciences, v. 54, no. 8, p. 1685-1698, accessed September 19, 2020.

DeVries, P., Burges, S.J., Daigneau, J., and Stearns, D., 2001, Measurement of the temporal progression of scour in a pool-riffle sequence in a gravel bed stream using an electronic scour monitor: Water Resources Research, v. 37, no. 11, p. 2805-2816, accessed September 23, 2020, https://doi.org/10.1029/2001WR000357.

DeVries, P., 2002, Bedload Layer Thickness and Disturbance Depth in Gravel Bed Streams: Journal of Hydraulic Engineering (New York, N.Y.), v. 128, no. 11, p. 983-991, accessed September 23, 2020.

DeVries, P., and Aldrich, R., 2015, Assessment approach for identifying compatibility of restoration projects with geomorphic and flooding processes in gravel bed rivers: Journal of Environmental Management, v. 56, p. 549-568.

Dragovich, J.D., and McKay, D.T., 2000, Holocene Glacier Peak lahar deposits in the lower Skagit River valley, Washington: Washington Geology, v. 28, no. 1, p. 19-21.

Geist, D.R., Abernethy, C.S., Hand, K.D., Cullinan, V.I., Chandler, J.A., and Groves, P.A., 2006, Survival, Development, and Growth of Fall Chinook Salmon Embryos, Alevins, and Fry Exposed to Variable Thermal and Dissolved Oxygen Regimes: Transactions of the American Fisheries Society, v. 135, no. 6, p. 1462-1477, accessed September 12, 2020.
Gendaszek, A.S., Magirl, C.S., Czuba, C.R., and Konrad, C.P., 2013, The timing of scour and fill in a gravel-bedded river measured with buried accelerometers: Journal of Hydrology (Amsterdam), v. 495, p. 186-196, accessed September 30, 2020 .

Gendaszek, A.S., Burton, K., Magirl, C.S., and Konrad, C.P., 2018, Streambed scour of salmon spawning habitat in a regulated river influenced by management of peak discharge: Freshwater Biology, v. 63, no. 8, p. 917-927, accessed September 30, 2020.

Gendaszek, A.S., Ablow, E., and Marks, D., 2020, Streambed scour of salmon (Oncorhynchus spp.) and steelhead (Oncorhynchus mykiss) redds in the South Fork Tolt River, King County, Washington: U.S. Geological Survey Scientific Investigations Report 2020-5044, 20 p, accessed September 30, 2020, at https://doi.org/10.3133/sir20205044.

Gendaszek, A.S., 2021, Accelerometer scour monitor data on the Sauk River, Washington, Water Year 2018: U.S. Geological Survey data release, https://doi.org/10.5066/P95KOMTC.

Gershunov, A., Shulgina, T., Clemesha, R.E.S., Guirguis, K., Pierce, D.W., Dettinger, M.D., Lavers, D.A., Cayan, D.R., Polade, S.D., Kalansky, J., and Ralph, F.M., 2019, Precipitation regime change in Western North AmericaThe role of Atmospheric Rivers: Scientific Reports, v. 9, no. 1, p. 9944, accessed October 10, 2020.

Gibbins, C.N., Shellberg, J., Moir, H., and Soulsby, C., 2008, Hydrological influences on adult migration, spawning, and embryo survival, in Sear, D.A., and deVries, P., eds., Salmon spawning habitat in rivers-Physical controls, biological responses, and approaches to remediation: American Fisheries Society Symposium, no. 65, American Fisheries Society, p. 195-223.

Goode, J.R., Buffington, J.M., Tonina, D., Isaak, D.J., Thurow, R.F., Wenger, S., Nagel, D., Luce, C., Tetzlaff, D., and Soulsby, C., 2013, Potential effects of climate change on streambed scour and risks to salmonid survival in snowdominated mountain basins: Hydrological Processes, v. 27, no. 5, p. 750-765, accessed September 3, 2020.

Greene, C.M., Jensen, D.W., Pess, G.R., Steel, E.A., and Beamer, E., 2005, Effects of Environmental Conditions during Stream, Estuary, and Ocean Residency on Chinook Salmon Return Rates in the Skagit River, Washington: Transactions of the American Fisheries Society, v. 134, no. 6, p. 1562-1581, accessed September 20, 2020. https://doi.org/10.1577/T05-037.1. 
Holtby, L.B., and Healey, M.C., 1986, Selection for Adult Size in Female Coho Salmon (Oncorhynchus kisutch): Canadian Journal of Fisheries and Aquatic Sciences, v. 43, no. 10, p. 1946-1959, accessed September 3, 2020.

Jaeger, K.L., Curran, C.A., Anderson, S.W., Morris, S.T., Moran, P.W., and Reams, K.A., 2017, Suspended sediment, turbidity, and stream water temperature in the Sauk River Basin, Washington, water years 2012-16: U.S. Geological Survey Scientific Investigations Report 2017-5113, 47 p., accessed September 5, 2020, at https://doi.org/10.3133/ $\operatorname{sir} 20175113$.

Klassen, H.D., and Northcote, T.G., 1986, Stream bed configuration and stability following gabion weir placement to enhance salmonid production in a logged watershed subject to debris torrents: Canadian Journal of Forest Research, v. 16, no. 2, p. 197-203, accessed September 30, 2020.

Lapointe, M., Eaton, B., Driscoll, S., and Latulippe, C., 2000, Modelling the probability of salmonid egg pocket scour due to floods: Canadian Journal of Fisheries and Aquatic Sciences, v. 57, no. 6, p. 1120-1130, accessed September 23, 2020.

Lisle, T.E., 1989, Sediment transport and resulting deposition in spawning gravels, north coastal California: Water Resources Research, v. 25, no. 6, p. 1303-1319, accessed September 30, 2020.

Mao, L., 2012, The effect of hydrographs on bed load transport and bed sediment spatial arrangement: Journal of Geophysical Research, v. 117, F3, p. n/a, accessed September 10, 2020.

May, C.L., Pryor, B., Lisle, T.E., and Lang, M., 2009, Coupling hydrodynamic modeling and empirical measures of bed mobility to predict the risk of scour and fill of salmon redds in a large regulated river: Water Resources Research, v. 45, no. 5, accessed September 5, 2020.

McKean, J., and Tonina, D., 2013, Bed stability in unconfined gravel bed mountain streams - With implications for salmon spawning viability in future climates: Journal of Geophysical Research. Earth Surface, v. 118, no. 3, p. 1227-1240, accessed September 3, 2020.

Moir, H.J., Gibbins, C.N., Buffington, J.M., Webb, J.H., Soulsby, C., and Brewer, M.J., 2009, A new method to identify the fluvial regimes used by spawning salmonids: Canadian Journal of Fisheries and Aquatic Sciences, v. 66, no. 9, p. 1404-1408, accessed September 30, 2020.
Montgomery, D.R., Buffington, J.M., Peterson, N.P., SchuettHames, D., and Quinn, T.P., 1996, Stream-bed scour, egg burial depths, and the influence of salmonid spawning on bed surface mobility and embryo survival: Canadian Journal of Fisheries and Aquatic Sciences, v. 53, no. 5, p. 1061-1070, accessed September 8, 2020.

Montgomery, D.R., Beamer, E.M., Pess, G.R., and Quinn, T.P., 1999, Channel type and salmonid spawning distribution and abundance: Canadian Journal of Fisheries and Aquatic Sciences, v. 56, no. 3, p. 377-387, accessed October 30, 2020 .

National Marine Fisheries Service, 2005, Endangered and threatened species-Final listing determinations for 16 ESUs of west coast salmon, and final 4(d) protective regulations for threatened salmonid ESUs: Federal Register, v. 70, no. 123, p. 37160-37204, accessed June 29, 2017, at URL.

Nehlsen, W., Williams, J.E., and Lichatowich, J.A., 1991, Pacific Salmon at the Crossroads - Stocks at Risk from California, Oregon, Idaho, and Washington: Fisheries (Bethesda, Md.), v. 16, no. 2, p. 4-21, accessed September 9, 2020.

Neiman, P.J., Schick, L.J., Ralph, F.M., Hughes, M., and Wick, G.A., 2011, Flooding in Western WashingtonThe Connection to Atmospheric Rivers: Journal of Hydrometeorology, v. 12, no. 6, p. 1337-1358, accessed September 8, 2020.

Shellberg, J.G., Bolton, S.M., and Montgomery, D.R., 2010, Hydrogeomorphic effects on bedload scour in bull char (Salvelinus confluentus) spawning habitat, western Washington, USA: Canadian Journal of Fisheries and Aquatic Sciences, v. 67, no. 4, p. 626-640, accessed September 30, 2020.

Smirnova, I., 1955, The effect of mechanical agitation at different periods of development on the eggs of autumn chum salmon (Oncorhynchus keta) [in Russian], Doklady Akademii nauk SSSR, v. 105, no. 4, p. 873-876: Translated from Russian by Fisheries Research Board of Canada Translation Series 230.

Steen, R.P., and Quinn, T.P., 1999, Egg burial depth by sockeye salmon ( Oncorhynchus nerka ) - Implications for survival of embryos and natural selection on female body size: Canadian Journal of Zoology, v. 77, no. 5, p. 836-841, accessed September 3, 2020. 
Tabor, R.W., Booth, D.B., Vance, J.A., and Ford, A.B., 2002, Geologic Map of the Sauk River 30- by 60-Minute Quadrangle, Washington: U.S. Geological Survey Miscellaneous Investigations Map I-2592, accessed

September 2, 2020, at https://pubs.usgs.gov/imap/i2592/.

Thorne, R.E., and Ames, J.J., 1987, A Note on Variability of Marine Survival of Sockeye Salmon (Oncorhynchus nerka ) and Effects of Flooding on Spawning Success: Canadian Journal of Fisheries and Aquatic Sciences, v. 44, no. 10, p. 1791-1795, accessed September 30, 2020.

U.S. Geological Survey, 2021, National Water Information System: U.S. Geological Survey web interface, https://doi.org/10.5066/F7P55KJN, accessed June 14, 2020, at https://waterdata.usgs.gov/nwis.
Veilleux, A.G., Cohn, T.A., Flynn, K.M., Mason, R.R., Jr., and Hummel, P.R., 2014, Estimating magnitude and frequency of floods using the PeakFQ 7.0 program: U.S. Geological Survey Fact Sheet 2013-3108, 2 p., accessed September 7, 2017, at https://doi.org/10.3133/fs20133108.

Warner, M.D., and Mass, C.F., 2017, Changes in the Climatology, Structure, and Seasonality of Northeast Pacific Atmospheric Rivers in CMIP5 Climate Simulations: Journal of Hydrometeorology, v. 18, no. 8, p. 2131-2141, accessed September 30, 2020.

Waples, R.S., Pess, G.R., and Beechie, T., 2008, Evolutionary history of Pacific salmon in dynamic environments:

Evolutionary Applications, v. 1, no. 2, p. 189-206, accessed September 8, 2020.

Wolman, M.G., 1954, A method of sampling coarse river-bed material: Transactions - American Geophysical Union, v. 35, no. 6, p. 951, accessed September 30, 2020. 

Publishing support provided by the U.S. Geological Survey Science Publishing Network, Tacoma Publishing Service Center For more information concerning the research in this report, contact the Director, Washington Water Science Center U.S. Geological Survey 934 Broadway, Suite 300

Tacoma, Washington 98402

https://www.usgs.gov/centers/wa-water 
$\frac{\mathbb{R}}{0}$ 